\title{
Hydrology in the Sea of Marmara during the last 23 ka: Implications for timing of Black Sea connections and sapropel deposition
}

\author{
L. Vidal, ${ }^{1}$ G. Ménot, ${ }^{1}$ C. Joly, ${ }^{1}$ H. Bruneton, ${ }^{1}$ F. Rostek, ${ }^{1}$ M. N. Çağatay, ${ }^{2}$ C. Major, ${ }^{3}$ \\ and E. Bard ${ }^{1}$ \\ Received 14 January 2009; revised 27 August 2009; accepted 5 October 2009; published 6 February 2010.
}

[1] Sediments deposited under lacustrine and marine conditions in the Sea of Marmara hold a Late Quaternary record for water exchange between the Black Sea and the Mediterranean Sea. Here we report a multiproxy data set based on oxygen and strontium isotope results obtained from carbonate shells, major and trace elements, and specific organic biomarker measurements, as well as a micropaleontological study from a ${ }^{14} \mathrm{C}$-dated sediment core retrieved from the Sea of Marmara. Pronounced changes occurred in $\delta^{18} \mathrm{O}$ and ${ }^{87} \mathrm{Sr} /{ }^{86} \mathrm{Sr}$ values at the fresh and marine water transition, providing additional information in relation to micropaleontological data. Organic biomarker concentrations documented the marine origin of the sapropelic layer while changes in $n$-alkane concentrations clearly indicated an enhanced contribution for organic matter of terrestrial origin before and after the event. When compared with the Black Sea record, the results suggest that the Black Sea was outflowing to the Sea of Marmara from the Last Glacial Maximum until the warmer Bølling-Allerød. The first marine incursion in the Sea of Marmara occurred at $14.7 \mathrm{cal}$ ka B.P. However, salinification of the basin was gradual, indicating that Black Sea freshwaters were still contributing to the Marmara seawater budget. After the Younger Dryas (which is associated with a high input of organic matter of terrestrial origin) both basins were disconnected, resulting in a salinity increase in the Sea of Marmara. The deposition of organic-rich sapropel that followed was mainly related to enhanced primary productivity characterized by a reorganization of the phytoplankton population.

Citation: Vidal, L., G. Ménot, C. Joly, H. Bruneton, F. Rostek, M. N. Çağatay, C. Major, and E. Bard (2010), Hydrology in the Sea of Marmara during the last $23 \mathrm{ka}$ : Implications for timing of Black Sea connections and sapropel deposition, Paleoceanography, 25, PA1205, doi:10.1029/2009PA001735.

\section{Introduction}

[2] The Sea of Marmara is connected to the Mediterranean Sea and the Black Sea through the Dardanelles and Bosphorus straits, with sill depths of $-80 \mathrm{~m}$ and $-35 \mathrm{~m}$, respectively. Sediments in the basin are a sensitive recorder of water mass exchanges between the Mediterranean and Black seas, which depend on Late Quaternary global sea level fluctuations [Zubakov, 1988]. Over a longer time scale, regional tectonic situation acting on the sill depth of the Çanakkale (Dardanelles) Strait is another factor [Yaltirak et al., 2002]. For the postglacial period, it has been suggested that a rapid rise in the level of the Black Sea was the major reason for the migration of Neolithic populations toward central Europe, an idea that is associated with the flood myth [Ryan and Pitman, 1999]. Nevertheless, the timing and nature (catastrophic versus gradual) of the latest connection between the Black Sea and the Mediterranean Sea through the Sea of Marmara during the period of the last deglaciation is debatable.

${ }^{1}$ CEREGE, Aix-Marseille Université, Collège de France, IRD, Europôle de l'Arbois, CNRS, Aix-en-Provence, France.

${ }^{2}$ EMCOL and Geological Engineering Department, Istanbul Technical University, Istanbul, Turkey.

${ }^{3}$ Department of Geology and Geophysics, Woods Hole Oceanographic Institution, Woods Hole, Massachusetts, USA.

Copyright 2010 by the American Geophysical Union. 0883-8305/10/2009PA001735\$12.00
[3] One reconstruction for water mass exchange between the basins was based on lithologic observations and marine fauna from Black Sea sediments [Ross and Degens, 1974; Jones and Gagnon, 1994; Ryan et al., 1997; Ballard et al., 2000; Major et al., 2002; Ryan et al., 2003]. In recent studies, the age of the latest shift from lacustrine to marine conditions in the Black Sea was given as 9.4 cal ka B.P. [Major et al., 2006; Bahr et al., 2006]. Ryan et al. [1997, 2003] developed a hypothesis for an abrupt flooding of the Black Sea based on falling interior lake levels that occurred at a time of rising global sea level while considering that the Bosphorus sill depth was equal or slightly higher than modern depth. If this situation persisted until the moment when the rising ocean penetrated the Bosphorus at approximately 9.4 cal ka B.P., conditions for a catastrophic flooding were met. Indeed, observations of erosional surfaces in the sedimentary structure of the Black Sea have suggested that the Black seawater level experienced low stands during the last glacial period [Chepalyga, 1985; Ryan et al., 1997; Görür et al., 2001; Ballard et al., 2000; Ryan et al., 2003; Kaplin and Selivanov, 2004]. However, the chronology of the terraces was poorly constrained and mainly based on the age of overlying sediments [Major et al., 2002; Popescu et al., 2004].

[4] An alternative view for the reconnection between the Black Sea and Mediterranean waters assumes that a positive water balance led to a Black Sea level rise above the Bosphorus sill depth at approximately 12 cal ka B.P., and permitted Black seawaters from overflowing into the Sea of 


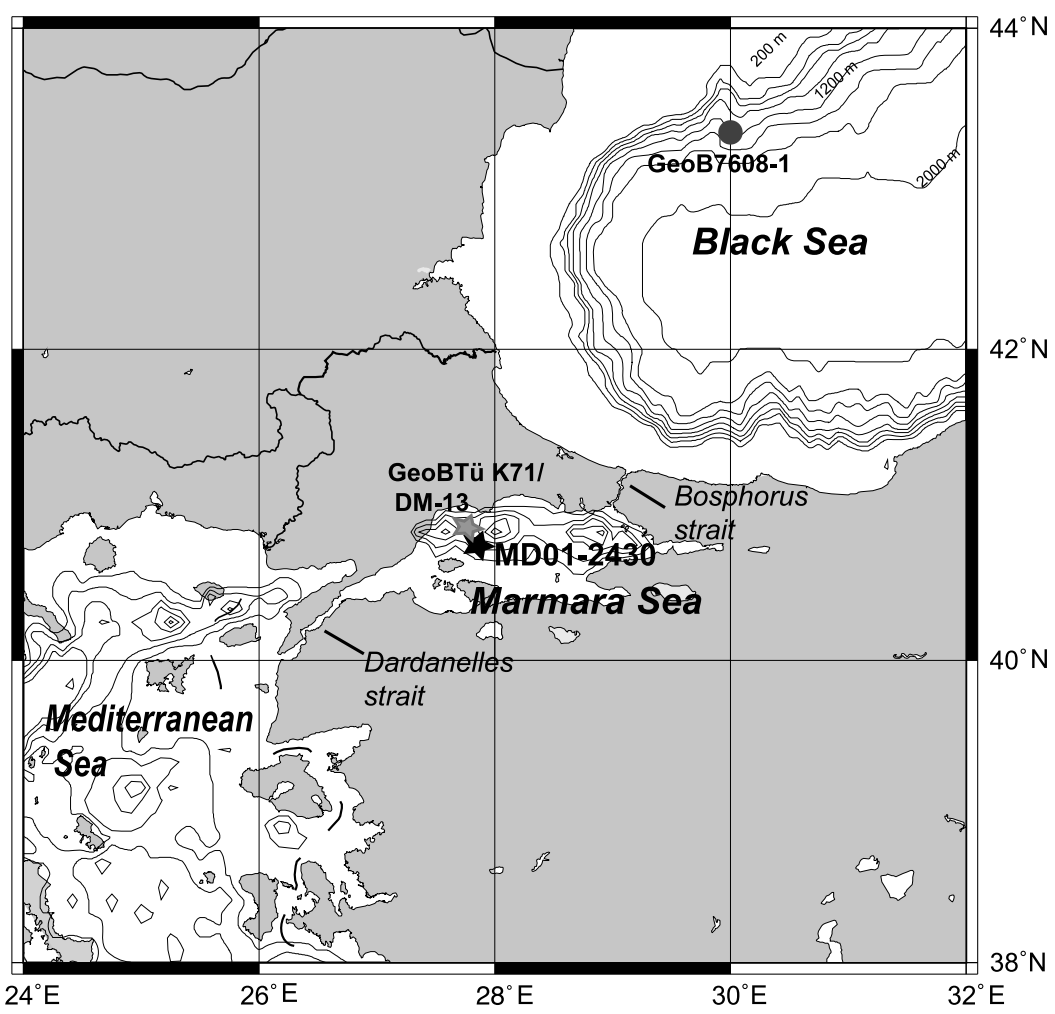

Figure 1. A map of the studied area and the location of core MD01-2430 (black star). The locations of the cores discussed in the text are shown: the gray star indicates the location of cores DM-13 [Çağatay et al., 2000] and GeoTü KL 71 [Sperling et al., 2003], and the gray circle is for core GeoB7608-1 [Bahr et al., 2006].

Marmara, a condition which resulted in the progressive and continuous replacement of fresher water in the Black Sea by more saline inflow allowing marine organisms to colonize Black Sea shelves [Aksu et al., 1999, 2002; Hiscott et al., 2007].

[5] Recent high-resolution studies aimed at the paleoenvironmental evolution of the Black Sea during the last $25 \mathrm{ka}$ have shown that hydrologic changes were linked to globally recognized climate events [Bahr et al., 2005, 2006; Major et al., 2006]. The highstand for Black Sea level occurred at the time of the collapse of the Eurasian ice sheets, synchronous with the North Atlantic Heinrich event 1 (H1) [Major et al., 2006; Bahr et al., 2006]. Lower lake levels due to reduced freshwater inputs and excess evaporation have been documented during the Bølling-Allerød (B/A) and preboreal warm periods [Major et al., 2006; Bahr et al., 2006], while increased riverine input and diminished evaporation have been stated to result in higher lake levels during the Younger Dryas (YD) cold period [Major et al., 2006]. However, the picture has been complicated by results based on the vegetation response to abrupt climate variability in the eastern Mediterranean region since pollen records from western Greece show the H1 and YD events as cold and dry [Tzedakis et al., 2004].

[6] The Sea of Marmara is located between the Dardanelles and Bosphorus straits and represents a key area for determining rising and falling water levels in the Black Sea (Figure 1). The location of the Sea of Marmara makes it possible to test whether a highstand (associated with a positive water budget) or a low stand (associated with a negative water budget) would have permitted/prevented the Black Sea from overflowing into the Sea of Marmara subsequent to the last glacial period. Rising and falling water levels also have implications for the deposition of sapropelic sediments in the Sea of Marmara after a marine reconnection [Çăgatay et al., 2000; Aksu et al., 2002]. A recent work based on Marmara Sea sediments has provided evidence that the deposition of the sapropelic layer (between 11.5 and 7.5 cal ka B.P.) was not likely due to a freshwater outflow from the Black Sea but most probably related to the global transgression and the concomitant reorganization of biogeochemical cycles associated with increasing productivity [Sperling et al., 2003]. However, information is missing regarding the exact origin and nature of deposited organic matter.

[7] Here, we present a study for paleoenvironmental multiproxy data and ${ }^{14} \mathrm{C}$ dating from a sediment core retrieved from the Sea of Marmara that includes both lacustrine and marine sediment units deposited during the last $23 \mathrm{ka}$. Hydrologic changes were reconstructed by measuring oxygen isotopic composition on ostracods and planktonic foraminifers, strontium isotope ratios on molluscs, major and trace elements, and specific organic biomarkers. Using this approach we refined the timing for the first marine intrusion in the Sea of Marmara, performed a comparison with hydrologic changes in the Black Sea for precise time intervals (LGM, H1, B/A, YD, during the sapropel deposition), and 


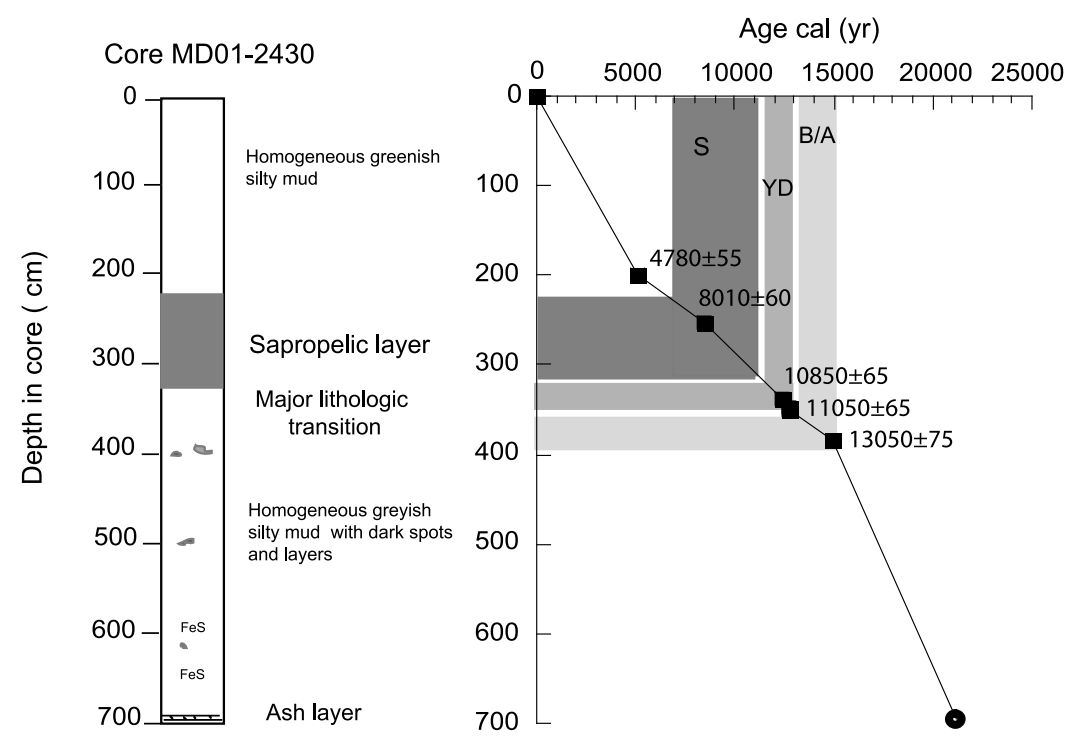

Figure 2. A lithological description and the age-depth relation for core MD01-2430. The age model was obtained using a linear interpolation between calibrated ${ }^{14} \mathrm{C}$ ages (black squares) and the position of the ash layer at $695 \mathrm{~cm}$ (black dot). Radiocarbon ages are also indicated. Shaded areas correspond to the sapropel (S) (dark gray), the Younger Dryas (YD) (medium gray), and the Bølling-Allerød (B/A) (light gray).

obtained detailed information on the organic matter composition within the sapropelic layer.

\section{Oceanographic Setting and Materials}

[8] In the Sea of Marmara at present, brackish waters from the Black Sea are confined to the surface layer, whereas salty waters with a Mediterranean origin enter the basin at depth resulting in a marked pycnocline at approximately $20-25 \mathrm{~m}$, separating the surface layer (mean salinity of 25 practical salinity unit (psu)) and the deep layer (mean salinity of 35 psu) [Ünlüata et al., 1990]. Brackish water fluxes are on the order of $649 \mathrm{~km}^{3} /$ year near the Bosphorus Strait and $830 \mathrm{~km}^{3} /$ year close to the Dardanelles Strait while deep salty water fluxes are on the order of $349 \mathrm{~km}^{3} /$ year and $530 \mathrm{~km}^{3} /$ year, respectively [Özsoy and Ünlüata, 1997]. When considering the modern hydrologic balance in the Sea of Marmara, additional freshwater water fluxes (river runoff, EliassenPalm (E-P)) are negligible as compared to exchanged water fluxes [Ünlüata et al., 1990; Özsoy and Ünlüata, 1997].

[9] The present study concerns core MD01-2430 $\left(40^{\circ} 47.81^{\prime} \mathrm{N}, 27^{\circ} 43.51^{\prime} \mathrm{E}\right)$ retrieved during the MD123/ MARMACORE cruise (R/V Marion Dufresne) in 2001. The core was collected on the western high separating the central basin and the Tekirda basin at $580 \mathrm{~m}$ water depth and is $29 \mathrm{~m}$ long (Figure 1). Our study was restricted to the upper $7 \mathrm{~m}$ (Figure 2) of the core. On board lithologic descriptions of core MD01-2430 revealed features characteristic of sediments from the Sea of Marmara [Çăgatay et al., 2000; Tolun et al., 2002] (Figure 2). The upper $230 \mathrm{~cm}$ consisted of a homogenous greenish silty mud. Between $230 \mathrm{~cm}$ and $320 \mathrm{~cm}$ a dark sapropel was observed. A marked boundary occurred at $350 \mathrm{~cm}$ and represented the transition from lacustrine to marine deposits. Beneath this level, sediments were gray with the occurrence of locally darker spots and thin layers con- taining pyrite. Two ash layers were documented at 695 and $1520 \mathrm{~cm}$.

\section{Methods}

[10] Stable isotopic measurements in planktonic foraminifera and benthic ostracods were determined in core MD012430.

[11] The planktonic foraminifer species Turborotalia quinqueloba dominated the foraminiferal assemblage throughout the marine unit $(0-348 \mathrm{~cm})$; thirty to sixty individuals in the small size fraction $(125-150 \mu \mathrm{m})$ were needed for isotopic measurements. T. quinqueloba (a subpolar species) is known to develop in relatively cool water masses in the Atlantic region and in the Mediterranean Sea and lives in the photic zone [Hemleben et al., 1989]. Depth habitat estimations vary between 25 and $100 \mathrm{~m}$ close to the pycnocline, with a growing season observed during late summer (September) [Schiebel and Hemleben, 2000; Volkmann and Mensch, 2001; Simstich et al., 2003]. In the Sea of Marmara, a two-layer circulation results in a marked pycnocline at approximately $25 \mathrm{~m}$, suggests that $T$. quinqueloba grows close to the surface, and that the depth habitat of this species is similar to that of alkenone producers.

[12] Within the lacustrine unit, the benthic ostracod species Candona angulata was found in all samples from 363 to $700 \mathrm{~cm}$. Only adult shells (approximately 20) were chosen for isotopic analyses. C. angulata lives in freshwater to oligohaline environments $(1 \%$ - $10 \%$ o) [Xia et al., 1997] and has been found as deep as $300 \mathrm{~m}$ in lakes [Griffiths et al., 1993]. Since freshwater ostracods molt their shells eight to nine times before maturity, the isotopic composition of a single shell represents a discrete set of hydrochemical conditions. For the Candonae group, adults dominate from autumn to early spring during the coldest period of the year 
[von Grafenstein et al., 1999]. Temperature-dependent isotopic fractionation between ostracods and the surrounding water has been experimentally tested using ostracod cultures [Xia et al., 1997]. An effect of $+2 \%$ for Candona sp. was estimated [Xia et al., 1997] and confirmed using measurements based on modern ostracods of the same species [von Grafenstein et al., 1999].

[13] In general, $\delta^{18} \mathrm{O}$ variations measured in lake sediment benthic ostracods are assumed to reflect the hydrologic balance of the lake (including the $\delta^{18} \mathrm{O}$ of precipitation, the E-P budget, runoff, catchment area size, etc.) rather than temperature changes [Leng and Marshall, 2004]. Indeed, the deep waters in lakes are rather uniform, cannot be colder than $4^{\circ} \mathrm{C}$, and are only slightly influenced by seasonal variability [von Grafenstein et al., 1999]. Sensitivity studies for the calcification temperature of benthic ostracods in response to different air temperature seasonalities indicate that deepwater temperature changes are negligible during colder climatic conditions (e.g., Younger Dryas), but that they should be considered in warmer climatic conditions [Danis et al., 2003]. In the Sea of Marmara, lacustrine conditions prevailed until circa 12 ka B.P. [Çăgatay et al., 2000]. Therefore, it is reasonable to consider that $\delta^{18} \mathrm{O}$ variations measured on ostracods in core MD01-2430 were mainly controlled by the regional water budget rather than by deep-water temperature changes.

[14] All of the stable isotopic analyses were performed at CEREGE using a Finnigan DELTA Plus mass spectrometer coupled to an automated carbonate preparation system (KIEL-KARBO III). The analytical precision based on NBS-19 measurements was better than $0.05 \%$ for $\delta^{18} \mathrm{O}$ and $\delta^{13} \mathrm{C}$. In this study, only the oxygen isotope data are presented since they provide information on either the water temperature or the water $\delta^{18} \mathrm{O}$, or both.

[15] Stable isotopic measurements were complemented by the micropaleontological study in order to estimate the contribution of brackish water species relative to freshwater species within the ostracod assemblage. A standard procedure for micropaleontological sample preparation was followed: aliquoted sediments were dried at $50^{\circ} \mathrm{C}$ and weighed before sieving in order to estimate abundances (individuals/g of sediment). The different species were determined following the taxonomy described by Bronshtein [1947], Schornikov [1969], Meisch [2000], and Nazik [2001]. The same approach was not conducted on the marine sequence due to the paucity of foraminiferal diversity and abundance.

[16] Sr isotope ratios were measured on identified mollusc shells in order to trace water mass source and mixing. The analyses were performed at CEREGE using the Finnigan TIMS. Instrumental precision was monitored with an analysis of the NBS-987 standard and was $27 \mathrm{ppm}(2$ sigma, $\mathrm{n}=7)$.

[17] The organic carbon (TOC) content of the samples was analyzed using the Walkley-Black method [Gaudette et al., 1974] which is conducted with a wet combustion of the sample with potassium dichromate and a back titration of excess potassium dichromate with $\mathrm{Fe}(\mathrm{II})$ ammonium sulfate. Minor and trace elemental analyses were carried out using an inductively coupled plasma-mass spectrometer (ICP-MS), at ACME, Vancouver. The analytical precision of the methods was better than $5 \%$ at a $95 \%$ significance level. The accuracy of the analysis was checked using a set of lake sediment standards. In this study we present only the molybdenum (Mo) content.

[18] At specific depths in the marine record the proportion of $n$-alkanes as well as specific biomarkers, characteristic of different phytoplankton taxa, were also analyzed. After freeze-drying and grinding, $1-5 \mathrm{~g}$ of sediment was extracted for biomarkers using an accelerated solvent extraction method (ASE 200 system, Dionex, California, USA). The total lipid extract was analyzed for alkenone concentrations with a gas chromatograph equipped with a flame ionization detector (GC-FID, GC 8065 Fisons Instruments). Analytical conditions were similar to those used by Sonzogni et al. [1997]. Total lipid extracts were then saponified and neutral lipids were extracted under strongly basic conditions. Compounds were finally separated into four fractions using Supelco LC-NH2 cartridges and a sequence of solvent mixtures of increasing polarity. The alcohol fractions were analyzed as their trimethylsilyl esters, after reaction with $N, O$-bis (trimethylsilyl) trifluoroacetamide (BSTFA $+1 \%$ TMCS) in dichloromethane. Biomarker concentrations were measured with a gas chromatograph coupled with a mass spectrometer (GC-MS). The analysis was conducted on a TraceDSQ with a $60 \mathrm{~m} \times 0.25 \mathrm{~mm} \times 0.1 \mu \mathrm{m}$ nonpolar fused silica capillary column DB-5-MS (J\&W) fitted with a $2.5 \mathrm{~m} \times 0.53 \mathrm{~mm}$ deactivated retention gap using helium as a carrier gas. The apolar fraction was analyzed for $n$-alkane concentrations by GC-FID under analytical conditions similar to those used for the alkenones. Different biomarkers (dinosterol, brassicasterol, C30 diol and ketol, and alkenones) were identified using a comparison with published mass spectra and relative retention times. Quantitation was determined using the relevant peak areas for biomarkers of interest, and internal standards. Dinosterol is produced by many dinoflagellates [Boon et al., 1979; Volkman et al., 1998] while brassicasterol is mainly delivered to sediments by diatoms [Volkman et al., 1998]. C30 1,15 diol and ketolol were used to estimate the abundance of eustimatophyte algae. C30 1,15 diol is biosynthesized by eustimatophytes [Volkman et al., 1999], and C30 1,15 ketolol is likely an oxidation product of C30 1,15 diol [Ferreira et al., 2001]. Long-chain alkenones are exclusively synthesized by some haptophyte algae [Marlowe et al., 1984].

\section{Chronology}

[19] The chronology in core MD01-2430 was based on six AMS ${ }^{14} \mathrm{C}$ ages performed on identified mollusc samples (Table 1). Sample preparation and AMS measurements were performed at the NOSAMS laboratory at Woods Hole Oceanographic Institution. Chronostratigraphy in core MD01-2430 was extended using the occurrence of the ash layer at $695 \mathrm{~cm}$. Due to its stratigraphic position, the ash layer could easily be correlated with similar levels documented in neighboring cores [Çăgatay et al., 2000; Wulf et al., 2002]. Tephra geochemistry performed on the layers supported a correlation with the marine tephra Y-2 from the Eastern Mediterranean Sea associated with the Santorini eruption dated at $18,000{ }^{14} \mathrm{C}$ yrs [Pichler and Friedrich, 1976]. AMS ages were corrected using a water reservoir age of 400 years 
Table 1. Radiocarbon Age Results and Age Control for Core MD01-2430

\begin{tabular}{ccccc}
\hline Sample Reference & Depth $(\mathrm{cm})$ & Species of Mollusc & ${ }^{14}$ C Age (year B.P.) & Cal Age $^{\mathrm{b}}($ year B.P.) \\
\hline OS-35404 & 200 & Scrobicularia plana & $4,780(55)$ & $5,056.5(185.5)$ \\
OS-40506 & 253 & Scrobicularia plana & $8,010(60)$ & $8,472.5(121.5)$ \\
OS-40513 & 337 & Arca sp. & $10,850(65)$ & $12,382(277)$ \\
OS-40514 & 347 & Arca sp. & $11,050(65)$ & $12,702(130)$ \\
OS-40515 & 349 & Arca sp. & $11,050(70)$ & $12,700(134)$ \\
OS-40516 & 384 & Turricaspia caspia & $13,050(75)$ & $14,890.5(316.5)$ \\
Y-2 Santorin & 695 & Terrestrial charcoal & $18,000^{\mathrm{c}}$ & 21,232 \\
\hline
\end{tabular}

${ }^{\mathrm{a}}$ Values in parentheses are age plus or minus 1sigma.

${ }^{\mathrm{b}}$ Calendar ages calculated using marine04.14c [Hughen et al., 2004].

${ }^{\mathrm{c}}$ Age from Wulf et al. [2002].

(for the molluscs samples) [Siani et al., 2000], and were then converted to calendar ages using the marine04 data set [Hughen et al., 2004] with Calib 5.01 software [Stuiver and Reimer, 1993] (Table 1). For the freshwater mollusc samples (Turricaspia caspia), we applied the same correction as for the marine species water reservoir age. Since we had no means for constraining this parameter during lacustrine conditions, we used the 400 year correction as an assumption. Recent studies have shown that Black Sea lacustrine reservoir ages may have varied from 0 to 1,500 years depending on water depth during the last deglaciation [Bahr et al., 2005; Major et al., 2006; Kwiecien et al., 2008]. If the Black Sea was overflowing into the Sea of Marmara during the "lacustrine" period, as we hypothesize, one may expect a similar reservoir age. However, a precise record of Black Sea reservoir age was not available. Therefore, we considered that a 400 year correction in the freshwater sample represented a compromise of the probable Marmara Sea lacustrine reservoir age between 0 and 1500 years. The age model of core MD01-2430 was constructed using a linear interpolation between calibrated ages (Figure 2). Mean sedimentation rates varied between $20 \mathrm{~cm} / \mathrm{ka}$ for the deglaciation period and $40 \mathrm{~cm} / \mathrm{ka}$ for the last glacial (lacustrine phase) and the Late Holocene. The temporal resolution of the records ranged between 200 and 500 years, depending on the sampling step $(5 \mathrm{~cm}$ or $10 \mathrm{~cm})$ and variations in the sedimentation rate. In sections 5 and 6 , all of the ages are given in calendar years before 1950 (ka B.P.).

\section{Results}

\subsection{Oxygen Isotopic Composition (on Foraminifers and Ostracods)}

[20] We paid special attention to planktonic foraminifer sample preparation. Shells were hand picked and measured from dry and wet samples in order to test the potential diagenetic effect of pyrite on $\delta^{18} \mathrm{O}$ values. In core MD01-2430, pyrite was present in almost every sample and often locked within foraminiferal chambers. Geochemical studies performed on sediments from the Sea of Marmara have documented differences between $\delta^{18} \mathrm{O}$ and $\delta^{13} \mathrm{C}$ values measured on dry and wet samples and it has been proposed that additional calcite dissolution through the oxidation of pyrite occurred during the drying process (at $50^{\circ} \mathrm{C}$ ), which in turn modifies isotope values [Sperling et al., 2002]. $\delta^{18} \mathrm{O}$ values from dry samples were depleted compared to wet samples (by approximately 1\%o) with a maximum depletion within organic carbon (TOC) rich sapropel while the deviation for $\delta^{13} \mathrm{C}$ was less pronounced $(<0.5 \%)$ [Sperling et al., 2002]. In core MD01-2430, the comparison between both sets of results showed no significant difference between the $\delta^{18} \mathrm{O}$ and $\delta^{13} \mathrm{C}$ values (Figure 3 ). This finding was also true for samples within the sapropel layer. The largest offsets were recorded for $\delta^{13} \mathrm{C}$ values with no systematic trend between wet and dry samples. The deviations (concerning 3 samples over 20) are likely linked to sample heterogeneity. In both cases (wet and dry), foraminifers without apparent pyrite in the chambers were chosen under the binocular microscope. Nevertheless, while a clear explanation for the differences was not obvious, the data indicated that sample preparation and the choice of clean foraminifers were important steps for working with a reductive sedimentary setting. In core MD012430, we considered the diagenetic effects for oxygen isotopic values as negligible.

[21] Variations in the $\delta^{18} \mathrm{O}$ values of T. quinqueloba $\left(\delta^{18} \mathrm{O}_{\text {for }}\right)$ spanned the last $12 \mathrm{ka}$, and $\delta^{18} \mathrm{O}_{\text {for }}$ values varied between $2.2 \%$ and $-0.3 \%$ (Figure 4 ). The highest value of $2.2 \%$ at $12 \mathrm{ka}$ B.P. was duplicated. After the high value at $12 \mathrm{ka}$ B.P., $\delta^{18} \mathrm{O}_{\text {for }}$ values decreased to approximately $1 \%$ and were stable between 11 and $7 \mathrm{ka}$ B.P. A progressive decrease started again at 7-8 ka B.P.

[22] For the lacustrine part of the sequence, the benthic ostracod oxygen isotopic $\left(\delta^{18} \mathrm{O}_{\mathrm{ostr}}\right)$ record covered the period from 23 to $13.4 \mathrm{ka}$ B.P., and showed three distinct patterns (Figure 5). From 23 to $18 \mathrm{ka} \mathrm{B.P.,} \delta^{18} \mathrm{O}_{\mathrm{ostr}}$ values were stable, with a mean value of $-5 \%$. The value of $-2.5 \%$ recorded at circa $21.5 \mathrm{ka}$ B.P. $(698 \mathrm{~cm})$ was sampled close to the ash layer deposit (at $695 \mathrm{~cm}$ ). The measurement of this sample, which seemed reworked, could not be duplicated (not enough material for remeasurement), and therefore will not be considered. Between 18 and 16 ka B.P., the $\delta^{18} \mathrm{O}_{\text {ostr }}$ values dropped by approximately $1 \%$, and from 16 to 13.4 ka B.P. showed an increase of approximately $4 \%$.

\subsection{Ostracod Assemblages}

[23] Ostracod assemblages in core MD01-2430 revealed that freshwater species were present all along the studied lacustrine sequence and dominated by Candona angulata. Brackish water species were also identified (mainly of the Loxoconcha and Leptocythere genus). However, the poor abundance of shells in these sediments (in average 20 individuals per $20 \mathrm{~g}$ of dry sediment) made the statistical robustness of the counts less reliable (Figure 5). Between 23 and $15 \mathrm{ka} \mathrm{B.P.,} \mathrm{the} \mathrm{record} \mathrm{of} \mathrm{freshwater} \mathrm{ostracod} \mathrm{percen-}$ tages documented the clear dominance of freshwater species and low abundances. From 15 to 13.4 ka B.P. (the level of 

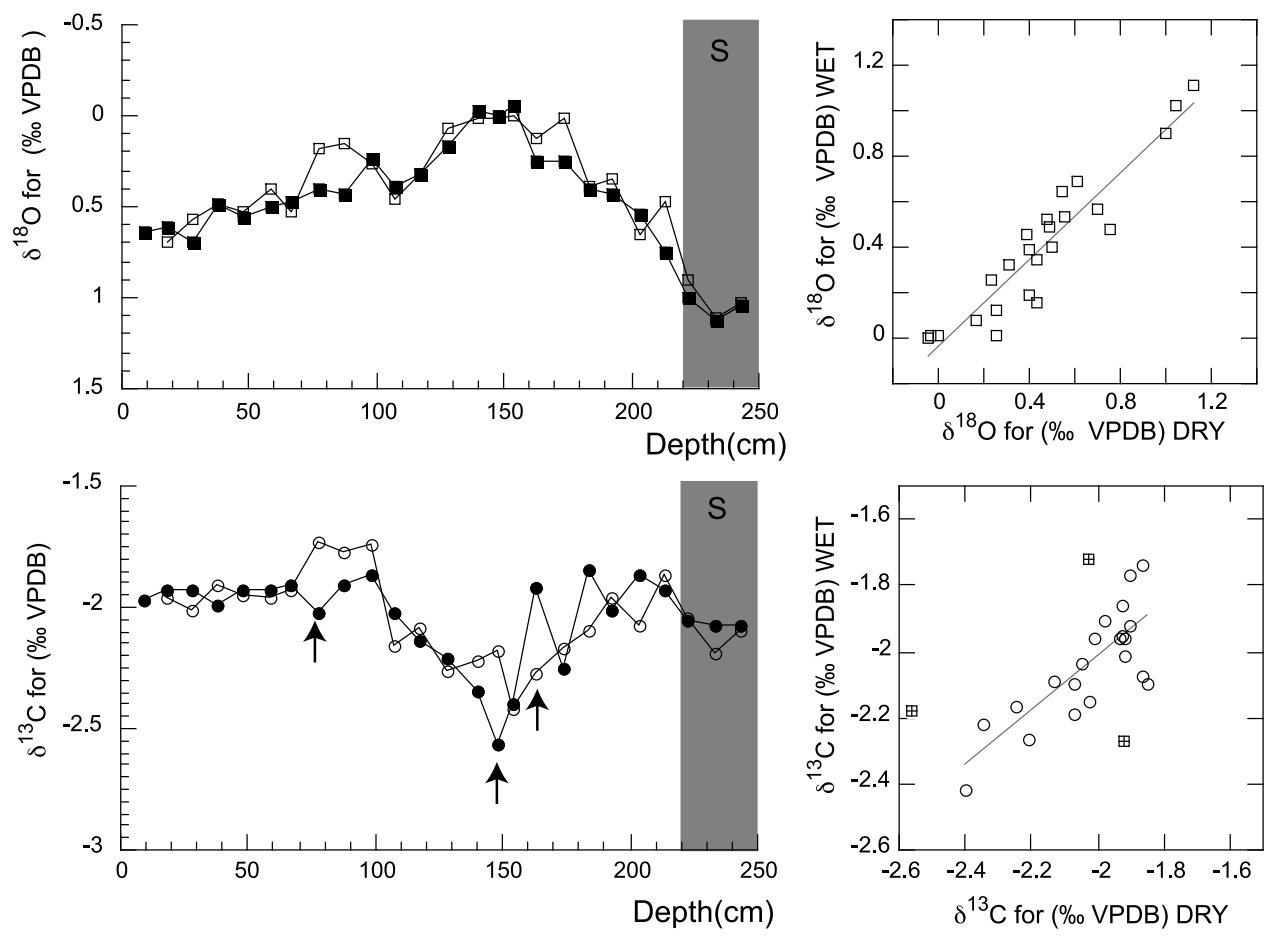

Figure 3. A comparison between foraminiferal $\delta^{18} \mathrm{O}$ and $\delta^{13} \mathrm{C}$ values obtained from dry and wet samples: $\delta^{18} \mathrm{O}$ (squares) and $\delta^{13} \mathrm{C}$ (dots) measured on T. quinqueloba from wet samples (solid symbols) and dry samples (open symbols) versus depth and the associated cross plots. The shaded area indicates the S layer.

complete disappearance of the ostracod fauna) the relative percentage of freshwater ostracods decreased by approximately $30 \%$ due to an increase in brackish water species accompanied by a maximum in the ostracod abundance (Figure 5). The trend was punctuated by recurrent peaks of brackish water species. However, a low abundance of shells made this last observation less significant.

\subsection{Sr Isotopes}

[24] $\mathrm{Sr}$ isotopic ratios are a powerful tool for studying paleohydrology and continental weathering. In fact, depending on the lithology of the drainage basin, $\mathrm{Sr}$ isotopic ratios from water samples enable one to track changing sources of water mixing [Elderfield, 1986; Capo et al., 1998]. In this study, two water systems were of interest: marine waters and freshwaters that alternatively filled the Sea of Marmara. A compilation based on modern data sets showed that these two systems had distinct $\mathrm{Sr}$ isotopic ratios and concentrations. Seawater $\mathrm{Sr}$ isotopic values are well homogenized and show a mean value of 0.7092 [Elderfield, 1986]. The main river systems (Danube, Don, Dniepr) bringing freshwater to this area through the Black Sea have relatively low $\mathrm{Sr}$ isotopic ratios (about 0.7085) as compared to the average world river waters [Palmer and Edmond, 1989]. The $\mathrm{Sr}$ concentration in seawater ( $8 \mathrm{ppm})$ is approximately 100 times higher than that in average riverine water [Capo et al., 1998], and approximately 30 times higher than that in rivers from the Black Sea [Major et al., 2006]. Due to much higher concentrations of strontium in marine waters relative to freshwaters, the Sr isotopic ratio in the Sea of Marmara is very sensitive to changes in water mass origin and in particular to marine water inflow.
[25] The Sr isotopic ratios of mollusc shells in core MD012430 documented two sets of values at $0.70916\left( \pm 4.410^{-6}\right)$ for marine samples, and at 0.70898 for freshwater samples (Figures 4 and 5). Although the last value was based on a single sample, we are confident that the value is reliable for several reasons.

[26] 1. The difference between both sets of samples $(180 \times$ $10^{-6}$ ) is significantly larger than the analytical error.

[27] 2. The obtained values can be linked to modern data sets. Marine samples record the $\mathrm{Sr}$ isotopic ratio of marine waters, whereas freshwater samples show values strikingly close to modern rivers (Sr ratios indicate a filling of the Sea of Marmara through the Black Sea under modern conditions).

[28] 3. The Sr isotopic value for the lacustrine sample was the same as the Black Sea value at the same time period [Major et al., 2006]. We believe that our $\mathrm{Sr}$ measurements are able to trace two water systems with marine and freshwater signatures. Our results indicate that the transition from freshwater low $\mathrm{Sr}$ ratios to seawater high $\mathrm{Sr}$ ratios occurred at $14.7 \mathrm{ka} \mathrm{B.P.}(380 \mathrm{~cm})$ (Figure 4 and 5).

\subsection{Major and Trace Elements}

[29] The TOC content in core MD01-2430 was relatively low and varied between $0.5 \%$ and $2.5 \%$ for the entire record (Figure 5). TOC values higher than 2\%, characteristic of the sapropel layer, were reached between 11.5 and $7.3 \mathrm{ka}$ B.P. Associated with sapropel, a high molybdenum (Mo) content was observed up to $150 \mathrm{ppm}$, suggestive of suboxic to anoxic environments (Figure 6). Peaks in Mo concentrations are supported by high values in the $\mathrm{Mo} / \mathrm{Al}$ ratio (data not shown). 


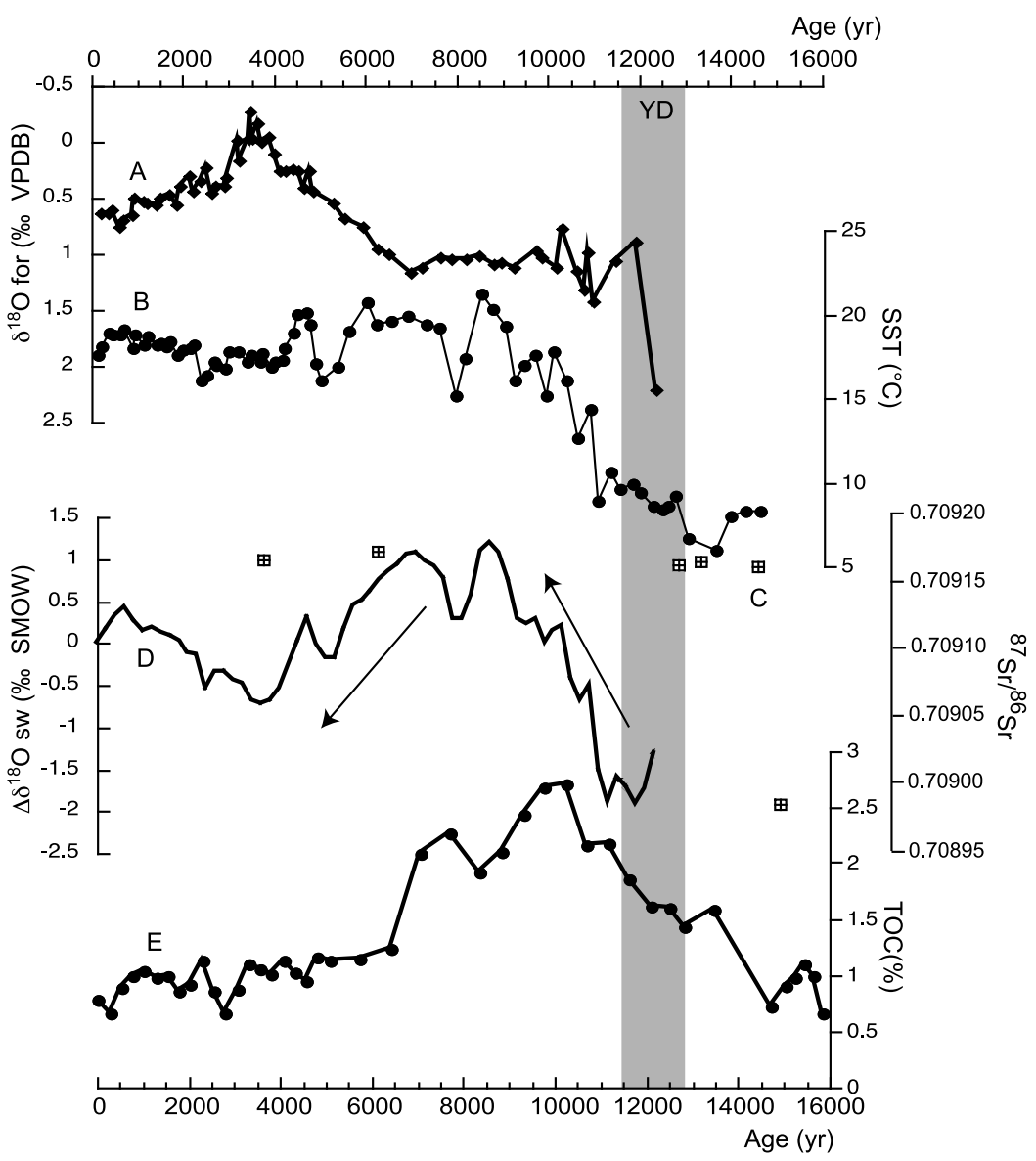

Figure 4. The hydrology of the marine phase in the Sea of Marmara expressed by (a) the $\delta^{18} \mathrm{O}$ of planktonic foraminifera (T. quinqueloba) $\left(\delta^{18} \mathrm{O}\right.$ for), (b) alkenone derived sea surface temperatures (SST), (c) the Sr isotope ratios on molluscs, (d) the estimated $\delta^{18} \mathrm{O}$ of seawater at the core location (normalized to core top values) $\left(\Delta \delta^{18} \mathrm{O}\right.$ sw), and (e) organic carbon content (TOC) (\%) versus age. The shaded area shows the YD period.

\subsection{Organic Biomarkers}

[30] To trace changes in the origin of organic matter in the Sea of Marmara, n-alkane concentrations were converted into the carbon preference index (CPI) (see the legend in Figure 6). CPI values were close to 1.5 all along the record, except for two periods at 12.5 and at $11 \mathrm{ka}$ B.P. (Figure 6). The odd-even preference index followed a similar pattern suggesting that CPI variations were more likely driven by shifts in the origin for the organic matter than by changes in the maturation of the organic matter. We have also presented variations for the sum of the three biomarkers: dinosterol, brassicasterol, and $\mathrm{C} 30 \mathrm{diol} / \mathrm{ketol}$ (Figure 6). While levels were absent or below detection for a large part of the marine phase record, the record exhibited a maxima associated with the highest TOC content, at $10 \mathrm{ka}$ B.P. Maximum concentrations were 8, 12, and $2 \mu \mathrm{g} / \mathrm{g} \mathrm{OC}$ for dinosterol, brassicasterol, and C30 diol/ ketol, respectively (Figure 6). The trends were confirmed by biomarkers known to be representative of the different phytoplanktonic communities. Examples are the loliolide and isololiolide measurements taken as a marker of diatoms [Menzel et al., 2003] in core MD012430 (data not shown). Surprisingly, the total alkenone concentrations followed a pattern different than other biomarkers in the sapropel; alkenone values exhibited minimum values (less than $100 \mathrm{ng} / \mathrm{g}$ OC), whereas other biomarkers peaked within the sapropel (Figure 6). However, two maxima were observed, one before the sapropel corresponding to the first CPI peak at $12.5 \mathrm{ka}$ B.P., and the second after the TOC maximum within the sapropel at $8.5 \mathrm{ka}$ B.P.

\subsection{Surface Water Temperatures and Salinity Reconstructions}

[31] The alkenone unsaturation index $\left(\mathrm{Uk}^{\prime}{ }_{37}\right)$ was analyzed in core MD01-2430 down to $368 \mathrm{~cm}$. Low concentrations of alkenones deeper in the core did not permit a significant $\mathrm{Uk}_{37}^{\prime}$ index estimation. However, the $\mathrm{Uk}_{37}^{\prime}$ derived SSTs record covered a longer time interval than the foraminiferal isotope record corresponding to brackish water conditions $(15-13 \mathrm{ka}$ B.P.) (Figure 4). For these samples the presence of alkenones characteristic of freshwater environments were not detected [Thiel et al., 1997; Schulz et al., 2000]. Before the Younger Dryas, a peak in C37 that corresponded with high CPI index values may suggest the contribution of reworked alkenones from allotochtonous organic matter (Figure 6). Again, an 


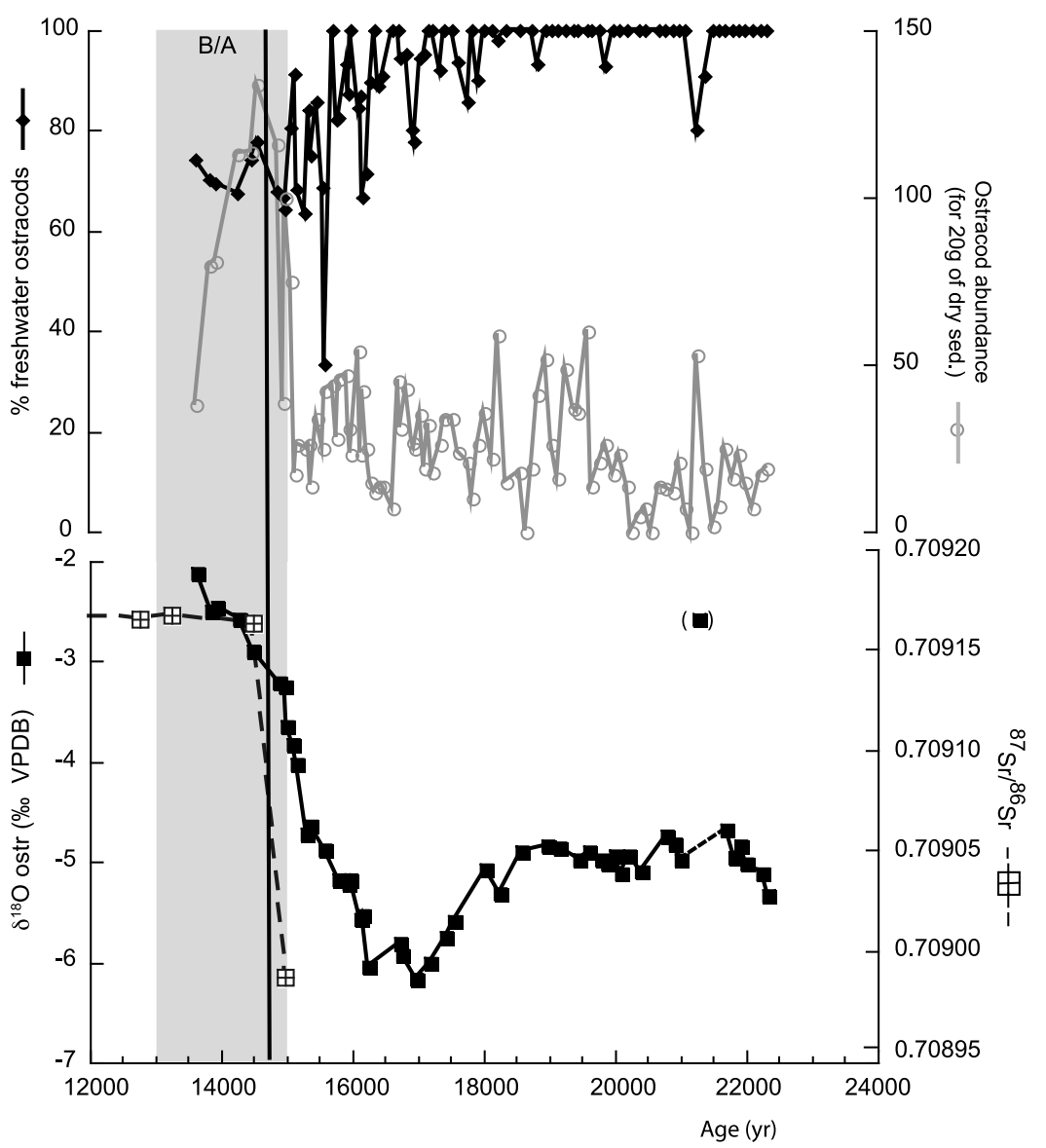

Figure 5. Hydrology of the lacustrine phase in the Marmara basin expressed by percentages of freshwater ostracods (\%), total abundances, the $\delta^{18} \mathrm{O}$ of benthic ostracods $(C$. angulata $)\left(\delta^{18} \mathrm{O}\right.$ ostr), and the Sr isotope ratios of molluscs versus age. The shaded area shows the B/A time interval. The vertical bar represents the time of the first marine water incursion in the Sea of Marmara.

unexpected alkenone distribution in these samples was not detected. Therefore, we applied the $\mathrm{Uk}_{37}^{\prime}$-temperature calibration equation of Prahl et al. [1988], which provides results similar to the general calibration from Müller et al. [1998]. The specific calibration proposed for the Mediterranean Sea was shown to record warmer SST values than expected in the sediments [Cacho et al., 2002]. A core top temperature of $18.5^{\circ} \mathrm{C}$ was close to the late summer surface temperature (September) according to modern hydrologic data from the Sea of Marmara [Besiktepe, 2003]. A stepwise increase in temperature started at $13 \mathrm{ka}$ B.P. and culminated at approximately $8 \mathrm{ka}$ B.P. After this period, SST values were more stable showing fluctuations within $2^{\circ} \mathrm{C}-3^{\circ} \mathrm{C}$ (Figure 4). The amplitude in the SST variation was approximately $15^{\circ} \mathrm{C}$ for the entire record and $10^{\circ} \mathrm{C}$ between the base of the record and the Late Holocene. The SST record did not show any cooling associated with the Younger Dryas event. Interestingly, studies showing SST reconstructions (based on alkenone values) resembled the Marmara record: a nearby core showed similar trends and values in the SST record [Sperling et al., 2003]. Cores from the eastern Mediterranean Sea also revealed a weak signal associated with the Younger Dryas event and a LGM-Late Holocene SST amplitude close to $8^{\circ} \mathrm{C}$ [Emeis et al., 2000; Essallami et al., 2007]. The similarities provide more confidence in the reliability of the alkenone derived SST record and suggest that it may contain some regional specificity superimposed on the global deglacial trend.

[32] $\mathrm{Uk}_{37}^{\prime}$ derived SSTs were combined with the $\delta^{18} \mathrm{O}$ record of T. quinqueloba in order to estimate surface water $\delta^{18} \mathrm{O}$ variations. Since both parameters were not measured on the same organism, we are aware that our estimation may contain some uncertainty. However, we assume that the depth habitat of $T$. quinqueloba was relatively stable, as documented from different hydrologic environments (see section 3) (which is also likely for phytoplankton). For the growing season, we found that the maximum occurrence of T. quinqueloba reported in September [Schiebel and Hemleben, 2000] while the phytoplanktonic blooming period for E. Huxleyi in the Sea of Marmara occurred in MayJune [Oguz and Merico, 2006]. Apart from the top $10 \mathrm{~m}$, hydrologic data from the Sea of Marmara indicates that the temperature difference between the summer (July) and the end of the summer (September) was small (less than $2^{\circ} \mathrm{C}$ ) [Besiktepe, 2003]. Taken together we assume that the past ecological behavior of the organisms would not have been drastically different from present conditions and that both 


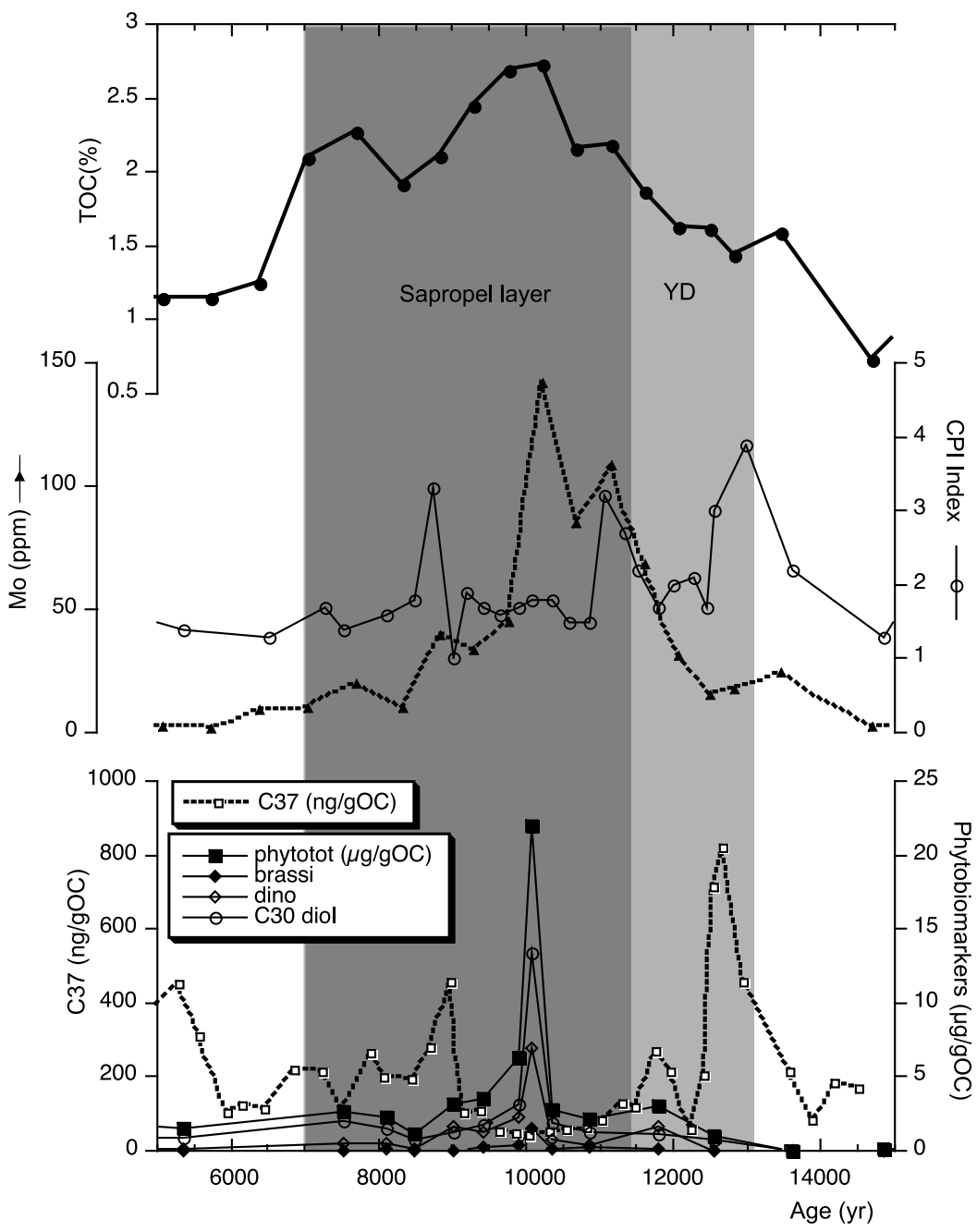

Figure 6. The nature and origin of organic matter during sapropel deposition in the Sea of Marmara traced with major and trace elements and biomarkers: total organic content (TOC) (\%), molybdenum contents (Mo) (ppm), CPI index (CPI $=0.5 *\left(\left[\mathrm{C}_{25}\right]+\left[\mathrm{C}_{27}\right]+\left[\mathrm{C}_{29}\right]+\left[\mathrm{C}_{31}\right]+\left[\mathrm{C}_{33}\right]\right) /\left(\left[\mathrm{C}_{24}\right]+\left[\mathrm{C}_{26}\right]+\left[\mathrm{C}_{28}\right]+\left[\mathrm{C}_{30}\right]+\right.$ $\left.\left[\mathrm{C}_{32}\right]+\left[\mathrm{C}_{34}\right]\right)$ ), dinosterol, $\mathrm{C} 30$ diol/ketol, brassicasterol concentrations $(\mu \mathrm{g} / \mathrm{g} \mathrm{OC})$, and alkenone concentration (ng/g OC) versus age. Concentrations are given relative to the total organic content values in order to take into account large variations within and without the sapropel layer. Shaded areas underline the $\mathrm{S}$ layer (with the TOC content $>2 \%$ ) and the YD period.

data sets could be combined in order to the estimate relative variations of $\delta^{18} \mathrm{O}$ from surface seawater.

[33] The calculated $\delta^{18} \mathrm{O}$ from seawater at the core location obtained using the approach developed by Rostek et al. [1993] represents differences to the core top values $\left(\Delta \delta^{18} \mathrm{O}\right.$ sw) and was corrected for global variations of $\delta^{18} \mathrm{O}$ from seawater [Duplessy et al., 1991] (Figure 4). The $\Delta \delta^{18} \mathrm{O}$ sw increased by approximately $2 \%-2.5 \%$ between 12 and $9 \mathrm{ka}$ B.P., suggesting a salinity increase in surface water or at pycnocline depth, followed by a salinity decrease between 8 and 3 ka B.P.

\section{Discussion}

[34] Multiproxy analyses performed on sediments from core MD01-2430 have provided new information regarding hydrologic evolution in the Sea of Marmara in relation to connections within the Black Sea and in the Mediterranean Sea. The following discussion concerns three main points: (1) the timing of the first marine incursion into the Sea of Marmara; (2) the water mass exchange with the Black Sea before and after the marine intrusion; and (3) the origin and nature of deposited organic matter within the sapropel layer.

\subsection{Marine Reconnection in the Sea of Marmara: Proxy-Related Timing for the First Marine Incursion}

[35] In core MD01-2430, the analyses of geochemical, sedimentological, and micropaleontological proxies were used to investigate the lacustrine-to-marine transition. Our results indicate that the chronology of this transition displayed a complex pattern in the Sea of Marmara. Sr isotopes in core MD01-2430 enabled the identification of water 
sources that successively filled the basin during the last $23 \mathrm{ka}$ B.P. (Figures 4 and 5). The transition between the two endmembers (fresh and marine waters) was dated at $14.7 \mathrm{ka}$ B.P. $(380 \mathrm{~cm})$ and corresponded to the first intrusion of marine waters into the Sea of Marmara. The sensitivity of the system due to the strong Sr concentrations difference between marine and fresh waters, implies a change from freshwater conditions to marine influenced environments that did not necessarily reach salinity levels similar to those of present conditions. As discussed in section 6.2.4, during the Holocene period while surface water salinity was varying, $\mathrm{Sr}$ isotopic ratios remained stable (Figure 4). A significant amount of alkenones produced by haptophyte algae were also present in the sediment and concomitant with a shift in $\mathrm{Sr}$ isotopes, consistent with the tolerance of calcareous nannoplankton (in particular E. huxleyi) to large salinity variations $(11 \%-41 \%)$ as observed in Black seawater and sediment samples [Giunta et al., 2007]. The carbonate nannoplankton community responded quickly to hydrologic changes, even if modern salinity conditions were not reached.

[36] On the other hand, micropaleontological data revealed different behavior. The freshwater benthic ostracod C. angulata (dominant in the assemblage within lacustrine sediments) was still present until $13.4 \mathrm{ka}(363 \mathrm{~cm})$, roughly $1 \mathrm{ka}$ after the first marine incursion (Figure 5). The cooccurrence of coccoliths and $C$. angulata implies salinity values in the water column in the Marmara basin close to $10 \%$ at the time of the marine incursion. The appearance of planktonic foraminifers only occurred at $12.4 \mathrm{ka}(345 \mathrm{~cm})$, approximately $2 \mathrm{ka}$ after salty waters with a Mediterranean origin entered the Marmara basin, when the salinity was high enough to allow the development of marine conditions (Figure 4). A recent study, conducted on shallow water cores in the Sea of Marmara, indicated that this timing also corresponded to a deepening of the Marmara Basin as indicated by benthic foraminiferal assemblages [McHugh et al., 2008]. A lithological boundary appeared at $13 \mathrm{ka}(350 \mathrm{~cm})$ (Figure 2), in line with earlier studies based on sedimentological and micropaleontological evidence from Marmara deep-sea sediments [Çăgatay et al., 2000; Aksu et al., 2002].

[37] Unfortunately, the ${ }^{87} \mathrm{Sr} /{ }^{86} \mathrm{Sr}$ data only go back to $15 \mathrm{ka}$ B.P. and do not provide any insight into water exchange before that time. On the basis of oxygen isotope and ostracod assemblages one may infer an earlier connection between the Mediterranean Sea and the Marmara Basin due to an increase in $\delta^{18} \mathrm{O}$ values and brackish water species at circa $16 \mathrm{ka} \mathrm{B.P.}$ (Figure 5). However, this timing is hardly compatible with regional sea level reconstructions that predict a sea level at least $20 \mathrm{~m}$ beneath the Dardanelles sill depth during this time period [Lambeck et al., 2007].

[38] Using sedimentology and micropaleontology data only, it is difficult to precisely document the onset of inflow for Mediterranean waters into the Sea of Marmara. Nevertheless, our results provide critical information regarding the sensitivity of biological indicators to hydrologic changes; whereas the $\mathrm{Sr}$ isotopic record is directly indicative of the origin of water filling the basin. We could trace the initiation of large hydrologic changes in the Sea of Marmara characterized by the first intrusion of Mediterranean waters. Additionally, the timing of $14.7 \mathrm{ka}$ B.P. perfectly fits with regional sea level reconstructions showing that at that time sea level was slightly above the Dardanelles sill depth $(-80 \mathrm{~m})$ [Lambeck et al., 2007]. The statement remains valid when different age models are considered based on varying reservoir ages for radiocarbon dated freshwater samples. The first occurrence of planktonic foraminifera, $2 \mathrm{ka}$ after the marine incursion, marks the setting of marine conditions linked with a probable significant flux of Mediterranean waters into the Sea of Marmara. Following Lambeck et al. [2007], the water level at $12.4 \mathrm{ka}$ B.P. was at least $30 \mathrm{~m}$ above the Dardanelles sill depth.

\subsection{Marmara Sea/Black Seawater Exchanges Before and After the Marine Reconnection}

[39] Between 23 and $18 \mathrm{ka}$ B.P., the $\delta^{18} \mathrm{O}_{\mathrm{ostr}}$ record in the Sea of Marmara indicates a rather stable freshwater environment with mean oxygen isotopic values of $-5 \%$ suggesting that no or little hydrologic changes occurred during this interval (Figure 5). The apparent steady state ended with a $1 \%$ drop in the $\delta^{18} \mathrm{O}_{\text {ostr }}$ record between 18 and $16 \mathrm{ka}$ B.P. (Figure 5). After $16 \mathrm{ka} \mathrm{B.P.,} \mathrm{the} \mathrm{trend} \mathrm{was} \mathrm{reversed} \mathrm{showing}$ an increase in $\delta^{18} \mathrm{O}_{\mathrm{ostr}}$ values up to $3 \%$ at the time of the first marine incursion in the Marmara basin at $14.7 \mathrm{ka}$ B.P. (Figure 5). As previously mentioned, hydrologic processes (i.e., precipitation and runoff versus evaporation and water mass mixing), rather than temperature changes, are likely to explain $\delta^{18} \mathrm{O}$ changes in the Marmara basin because the observed $\delta^{18} \mathrm{O}$ increase would indicate (considering only temperature) a decrease of more than $10^{\circ} \mathrm{C}$ in deep-water lake temperatures which seems unrealistic for this time interval.

[40] In the following discussion, the hydrologic history for the Sea of Marmara will be divided into five time intervals and compared with the Black Sea $\delta^{18} \mathrm{O}_{\mathrm{ostr}}$ record [Bahr et al., 2006]. Both records present striking similarities for trends and values (Figure 7).

\subsubsection{Phase 1: 23-18 ka B.P.}

[41] Between 23 and $18 \mathrm{ka}$ B.P., the Marmara basin exhibited a stable hydrologic state (Figures 5 and 7). An identical trend and absolute values were observed for the Black Sea $\delta^{18} \mathrm{O}_{\text {ostr }}$ record suggesting that both areas were influenced by similar climate conditions and that the waters in both basins had a common origin. During the Last Glacial Maximum (LGM), northern Eurasia was covered with massive icecaps that provided meltwaters to the Black Sea. The modern drainage area of the Black Sea compared with the Sea of Marmara also prevailed during glacial times [Mangerud et al., 2004]. Similarities in oxygen isotopic records imply that the Black Sea was likely to overflow into the Sea of Marmara (Figure 7), a finding that may contradict the occurrence of erosional surfaces in the sedimentary structure of the Black Sea likely representative of past low stands in the Black Sea during the last glacial period [Chepalyga, 1985; Ryan et al., 1997; Görür et al., 2001; Ballard et al., 2000; Kaplin and Selivanov, 2004]. However, the chronology of these terraces is poorly constrained [Major et al., 2002; Popescu et al., 2004].

\subsubsection{Phase 2: 18-16 ka B.P.}

[42] Between 18 and 16 ka B.P., a $1 \%$ drop in the $\delta^{18} \mathrm{O}_{\text {ostr }}$ of core MD01-2430 exactly corresponded to a $\delta^{18} \mathrm{O}$ decrease 

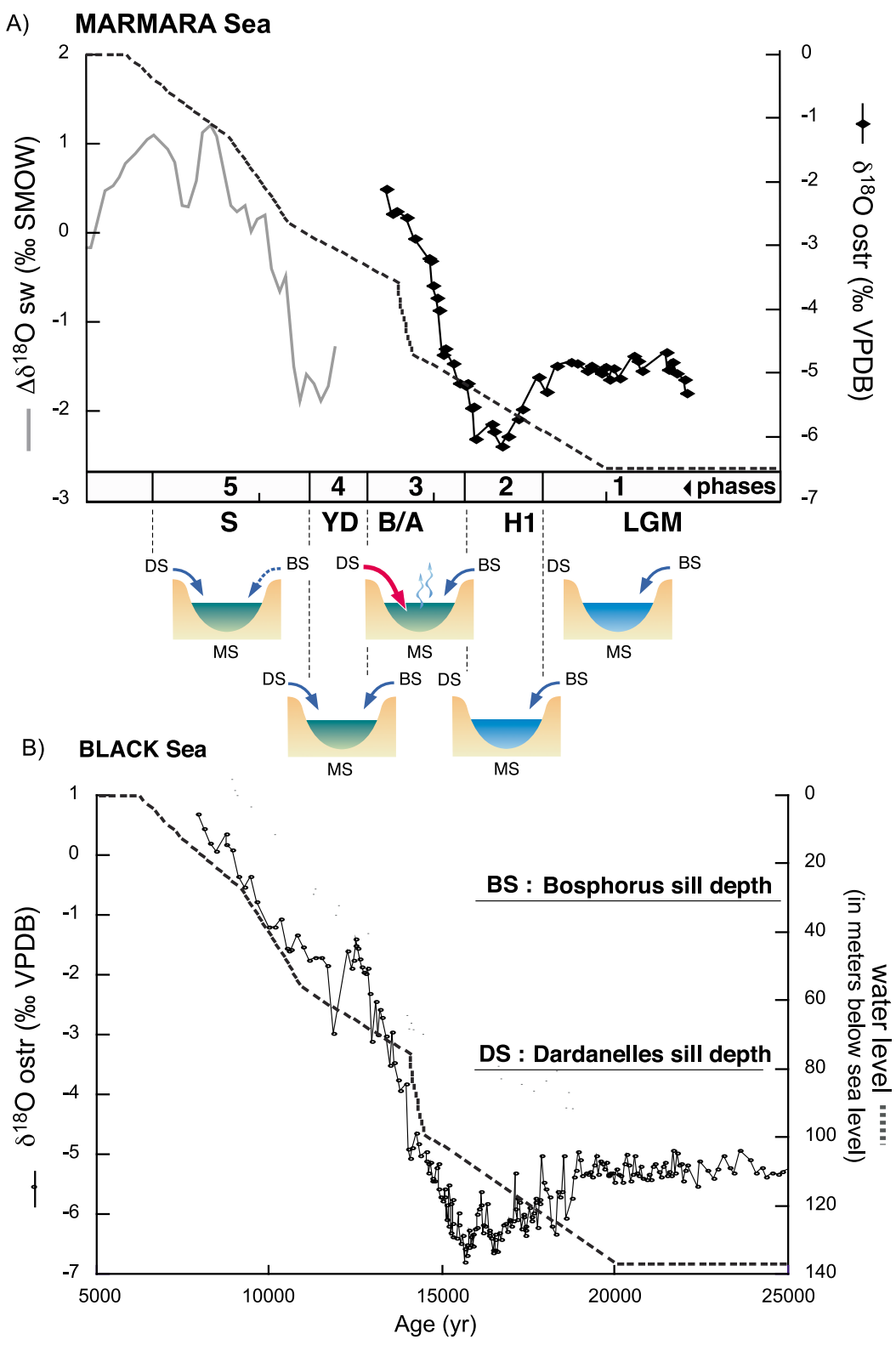

Figure 7. A comparison between (a) the Sea of Marmara and (b) the Black Sea hydrologic evolution and global sea level for the last $23 \mathrm{ka}$ and the hypothetical representation of different hydrologic phases between $23 \mathrm{ka}$ and $5 \mathrm{ka}$ B.P. Dashed curves show the global sea level evolution [Lambeck et al., 2002] in Figures 7a and $7 \mathrm{~b}$. Figure 7a shows $\delta^{18} \mathrm{O}$ ostr (C. angulata) (black symbols and right axis) and the estimated $\Delta \delta^{18} \mathrm{O}$ sw at the core location (gray curve and left axis) (negative values indicate fresher conditions, and positive values indicate saltier conditions compared to the modern situation). Figure $7 \mathrm{~b}$ shows $\delta^{18} \mathrm{O}$ ostr (C. angulata) in core GeoB7608-1 from the Black Sea [Bahr et al., 2006]. On the right axis, the modern Bosphorus sill depth and the Dardanelles sill depth are indicated. In the schematic representations corresponding to phases 1-5, BS represents the Bosphorus sill depth, DS represents the Dardanelles sill depth, and MS represents the Sea of Marmara. Arrows indicate water masses entering the Sea of Marmara through the BS and/or the DS. Dashed arrows represent a smaller water flux than solid arrows.

as recorded in western Black Sea sediments (Figure 7). Previous studies have interpreted this signal in the Black Sea as the signature of $\delta^{18} \mathrm{O}$-depleted meltwater pulses that are supported by high $\mathrm{Sr}$ isotopic ratios indicating an anom- alous sediment contribution to the Black Sea from a northward origin [Major et al., 2006]. As previously suggested, this event resulted from the collapse of the Eurasian ice sheet concomitant with the North Atlantic Heinrich event 1 (H1) 
[Bahr et al., 2006; Major et al., 2006]. This statement may not be valid when considering a recent age model for the Black Sea record, taking into account new estimations for the Black Sea reservoir age [Bahr et al., 2008]. However, assuming a connection between the basins, the enhanced flux of isotopically depleted freshwater would have lowered the $\delta^{18} \mathrm{O}$ of Marmara lake waters.

\subsubsection{Phase 3: $16-12.8$ ka B.P.}

[43] After 16 ka B.P., about 1 kyr before the BøllingAllerød (B/A) warm period, the $\delta^{18} \mathrm{O}_{\text {ostr }}$ record showed an increase of approximately $3 \%$ up to the point of the marine connection in the Sea of Marmara at 14.7 ka B.P. (Figure 7). An increase was also observed in the Back Sea $\delta^{18} \mathrm{O}$ record (Figure 7). The pre-B/A period is characterized by warm and dry conditions as reported for the Mediterranean region [Harrison et al., 1996; Tzedakis et al., 2004], potentially resulting in an increase in the regional evaporation/precipitation ratio. Additionally, recent studies have suggested that during warm periods (e.g., B/A), the Black Sea level recorded a low stand (probably beneath the Bosphorus strait level) in response to excess evaporation [Major et al., 2006]. Indeed, a stillstand for Marmara lake levels just before the marine reconnection has been recently proposed, related to the occurrence of a paleoshoreline at $-95 \mathrm{~m}$ [McHugh et al., 2008]. An increase in local evaporation could have led to a progressive salinification of the Marmara basin and explains the trend toward higher $\delta^{18} \mathrm{O}_{\text {ostr }}$ values. Ostracod assemblages in core MD01-2430 also show a slight increase in brackish water species that stabilize at the level of the marine connection at 14.7 ka B.P., suggesting that the basin may have experienced short periods of excess evaporation (Figure 5).

[44] On the other hand, a similar amplitude for $\delta^{18} \mathrm{O}$ signals in the Marmara Basin and in the Black Sea observed between 16 and 14.7 ka B.P., points to an alternative explanation for the isotopic signals. Since both basins are different in size and in volume, one would not expect similar isotopic trends in response to a local increase in evaporation. We suggest that the most probable cause for the steady $\delta^{18} \mathrm{O}_{\mathrm{ostr}}$ increase in the Sea of Marmara and in the Black Sea was linked to an increase in precipitation water $\delta^{18} \mathrm{O}$ values $(3 \%$ - $4 \%$ ) as documented in central Europe during the B/A period [von Grafenstein, 2002]. The $\delta^{18} \mathrm{O}$ signal was then transferred to the Marmara Basin through water exchange with the Black Sea. Also, low ${ }^{87} \mathrm{Sr} /{ }^{86} \mathrm{Sr}$ values $(0.70898)$ in the lacustrine sample from core MD01-2430 were the same as for Black Sea values of the same time period [Major et al., 2006], and represents outflow from the Black Sea into the Marmara Basin. Recent work has estimated relatively high precipitation over Central Turkey during the B/A period [Jones et al., 2007]; this humid period would have contributed to maintain the Black Sea to its outlet level.

[45] After $14.7 \mathrm{ka}$, the Sea of Marmara was influenced by both Mediterranean and Black seawaters. A significant increase in brackish water ostracod species was observed associated with the highest values in total ostracod abundance between 14.7 and 13.4 ka B.P. (Figure 5). However, the persistence of ostracod fauna, roughly $1 \mathrm{ka}$ after the marine intrusion indicates that salinification of the basin was slow, likely due to the overflowing of brackish waters from the Black Sea. Hydraulic modeling studies have shown that progressive salinification in the Sea of Marmara (over thousand year) imply a relatively strong outflow from the Black Sea that would have weakened the marine water inflow [Myers et al., 2003; Lane-Serff et al., 1997]. Black Sea level must have been maintained above the Bosphorus sill depth to permit a connection with the Sea of Marmara. The role of other potential connection routes between both basins (apart from the Bosphorus strait), such as in the Gulf of IzmitSakarya Valley, should also be considered but require further evaluation [Çăgatay et al., 2000; Kerey et al., 2004].

\subsubsection{Phase 4: 12.8-11.5 ka B.P.}

[46] The YD time interval was, unfortunately, poorly represented in core MD01-2430. Salinity reconstructions indicate relatively high values, although based only on one isotopic measurement (Figure 4). Interestingly, the same trend in salinity was observed in a nearby core showing a better resolution for this time interval [Sperling et al., 2003]. In core MD01-2430, a marked peak in the n-alkanes-based index (CPI) was documented and indicates an increase of organic material of terrigenous origin (Figure 6). Reduced evaporation rates (even though precipitation and runoff were also reduced) due to cold temperatures and ice cover have been linked to high water levels in the Black Sea during the YD period [Ryan et al., 2003; Major et al., 2006; Eriş et al., 2007]. A contrasting picture has been presented based on pollen data showing cold and dry conditions in Eastern Europe (Greece) for the same time period [Tzedakis et al., 2004]. In the Sea of Marmara, high CPI values could be linked to material transported with the overflowing waters from the Black Sea into the Sea of Marmara, in agreement with a positive water budget in the Black Sea. We suggest that the connection between both basins would have persisted from the LGM to the end of the YD.

[47] After $11.5 \mathrm{ka}$ B.P. an estimation for $\Delta \delta^{18} \mathrm{Osw}$ in core MD01-2430 indicates that surface water salinity continued to increase until $9 \mathrm{ka}$ B.P. confirming that the Black Sea outflow was negligible at the onset of sapropel deposition (11.5-7 ka B.P.) in the Sea of Marmara (Figure 4 and phase 5 in Figure 7), in agreement with Sperling et al. [2003]. Indeed, the rise of global sea level at that time enhanced the exchange of saline Mediterranean waters within the Sea of Marmara. However, a significant outflow of Black seawater in the Sea of Marmara started again at approximately 9 ka B.P., as indicated by the salinity decrease possibly due to an increase in regional precipitation [Sperling et al., 2003; Mudie et al., 2002; Feurdean et al., 2008] (Figures 4 and 7). These results suggest that both basins disconnected during a short period from 11.5 to approximately 9 ka B.P., consistent with a late connection of the Black Sea with Mediterranean origin waters between 9 and 8 ka B.P. [Sperling et al., 2003; Bahr et al., 2006; Major et al., 2006].

\subsection{Origin of the Organic Matter During Sapropel Deposition (Phase 5)}

[48] Sedimentary records of biomarkers and redox sensitive elements show that the sapropel deposition in core MD01-2430 took place in several steps. The CPI index 
suggests an enhanced influx of organic matter of terrigenous origin before the onset of sapropel deposition, during the YD (Figure 6 and phase 4 in Figure 7), consistent with earlier observations of low $\delta^{13} \mathrm{C}$ values for organic matter and organic biomarkers [Tolun et al., 2002]. A simultaneous peak in alkenone concentrations suggests enhanced production by haptophytes due to fertilization by river-borne nutrients (Figure 6). During that time period the Black Sea experienced a positive water balance through enhanced river input transmitted to the Sea of Marmara [Major et al., 2006; Eriş et al., 2007], a situation, which likely led to strong stratification of the water column in this basin.

[49] After the YD, between 11.5 and 7 ka B.P., deposition of the TOC-rich sapropel layer (values $>2 \%$ ) occurred when surface salinity increased (Figures 4 and 7). Onset of the sapropel layer, at $11 \mathrm{ka}$ B.P., is associated with high CPI index values indicating the deposition of organic matter of terrestrial origin. At $10 \mathrm{ka} \mathrm{B.P.,} \mathrm{maxima} \mathrm{in} \mathrm{TOC} \mathrm{are} \mathrm{associ-}$ ated with maxima in Mo and in selected phytoplanktonic biomarkers, as well as with a minimum in CPI values (Figure 6). Mo enrichment in marine sediments are limited to anoxic and suboxic environments where sulfate reduction occurs [Crusius et al., 1996; Zheng et al., 2000]. In these environments, Mo is removed from bottom waters through precipitation as a sulfide and adsorbed onto settling particulate debris (organic matter) [Piper and Isaacs, 1995; Mercone et al., 2001] providing a link between authigenic Mo accumulations and high carbon flux to the sediments, a finding that is confirmed by a maxima in phytoplanktonic biomarkers and a minima in the CPI index (Figure 6). However, enhanced productivity appears to be associated with a reorganization of the phytoplanktonic community. While the alkenone profile shows a maximum slightly before sapropel deposition indicating that haptophytes are important in the phytoplanktonic community, biomarkers attributed to dinoflagellates, eustigmatophytes, and diatoms reached a maximum at $10 \mathrm{ka}$ B.P. These pronounced maxima suggest a phytoplanktonic origin for organic matter within the sapropel layer, as also observed in nearby cores from the Sea of Marmara [Tolun et al., 2002], consistent with the sequence of events as described by Menzel et al. [2003] for Pliocene sapropels in the Mediterranean Sea with an increase of river discharge and nutrients leading to enhanced biological productivity causing the export production of organic matter to the seafloor. In the case of the Sea of Marmara, the transgression linked to the filling up of Mediterranean waters at the onset of the sapropel layer may have enhanced phytoplanktonic productivity. As a consequence, oxygen depletion and bottom water anoxia occurred, which in turn resulted in increased preservation of settling organic matter. Our results suggest that the deposition of the sapropel layer in the Sea of Marmara was largely controlled by enhanced primary productivity, in line with previous studies [Sperling et al., 2003], and that variable hydrologic conditions led to changes in the phytoplanktonic population. At the same time, increasing salinity in the Marmara Basin suggests no or a weak connection with the Black Sea. The late connection between both basins at approximately $9 \mathrm{ka}$ B.P., as indicated by decreasing surface salinity, is supported by an increased settling of organic material with a terrestrial origin (Figures 4, 6 , and 7).

\section{Conclusion}

[50] The multiproxy analyses performed on sediment core MD01-2430 documented hydrologic evolution in the Sea of Marmara during the last $23 \mathrm{ka}$ B.P. Between 23 and $16 \mathrm{ka}$ B.P., relatively low oxygen isotopic values $(-5 \%$ o to $-6 \%$ ) in the Sea of Marmara indicate that the basin was filled with meltwater, while enriched $\delta^{18} \mathrm{O}$ precipitation led to a gradual increase in the oxygen isotopic composition in the Marmara basin from $16 \mathrm{ka}$ to $14.7 \mathrm{ka}$. A comparison of $\delta^{18} \mathrm{O}$ records in the Sea of Marmara and in the Black Sea supports the occurrence of a hydrologic connection between both basins during the following climate periods: LGM, H1, B/A and YD. The finding has implications for the Black Sea level, which had to be maintained close to Bosphorus sill depth in order to permit fresh water outflow into the Sea of Marmara from the LGM to the end of the YD, and brings into question the existence of low water levels in the Black Sea during glacial periods. Further isotopic analysis on Marmara and Black Sea sequences could provide evidence regarding the occurrence of low stands in the Black Sea on time scales older than $23 \mathrm{ka}$.

[51] The onset of the latest incursion of Mediterranean waters in the Sea of Marmara was refined at $14.7 \mathrm{ka}$ B.P., based on $\mathrm{Sr}$ isotope data. However, marine conditions were established gradually, taking about $2 \mathrm{ka}$ for euryhaline Mediterranean organisms to colonize the Sea of Marmara, a finding that is consistent with a significant fresh water outflow from the Black Sea into the Marmara until the end of the YD. Therefore, using geochemical, micropaleontological and sedimentological tracers has helped us to constrain the response of the system to hydrologic changes and may provide important information for hydrologic modeling studies.

[52] Finally, sapropel deposition occurred during a period of no or a weak connection between both basins, and was characterized by a different origin for organic matter with terrigenous and marine inputs. Organic matter of a terrigenous origin was documented during the YD while during the sapropel the deposition marine organic matter dominated the organic fraction. One interpretation was that water stratification during the YD was a prerequisite for increasing productivity during the sapropel, and that the outflow of freshwater from the Black Sea was not the main factor. Additionally, the hydrologic context during sapropel deposition led to changes in the phytoplankton population. Both basins reconnected between 9 and $8 \mathrm{ka}$ permitting the setting for an estuarine type circulation in the Sea of Marmara (close to modern conditions).

[53] Acknowledgments. We acknowledge support from INSU and the French Polar Institute IPEV, which provided the R/V Marion Dufresne during the MARMACORE Cruise in 2001. We thank U. Sancar for TOC analysis; N. Buchet, C. Pailles, K. Tachikawa, and Y. Ternois for sampling work; and G. Soulet for fruitful discussions. We thank J. J. Motte of the drawing group at CEREGE for his contributions to Figure 7. The authors are grateful to A. Bahr and Editor G. Dickens for helpful comments and reviews of the manuscript. 


\section{References}

Aksu, A. E., R. N. Hiscott, and D. Yaşar (1999), Oscillating Quaternary water levels of the Marmara Sea and vigorous outflow into the Aegean Sea from the Marmara Sea-Black Sea drainage corridor, Mar. Geol., 153, 275302, doi:10.1016/S0025-3227(98)00078-4.

Aksu, A. E., R. N. Hiscott, P. J. Mudie, A. Rochon, M. A. Kaminski, T. Abrajano, and D. Yaşar (2002), Persistent Holocene outflow from the Black Sea to the eastern Mediterranean contradicts Noah's flood hypothesis, GSA Today, 12(5), 4-10, doi:10.1130/10525173(2002)012<0004: PHOFTB $>2.0$. CO;2.

Bahr, A., F. Lamy, H. Arz, H. Kuhlmann, and G. Wefer (2005), Late glacial to Holocene climate and sedimentation history in the NW Black Sea, Mar. Geol., 214, 309-322, doi:10.1016/ j.margeo.2004.11.013.

Bahr, A., H. W. Arz, F. Lamy, and G. Wefer (2006), Late glacial to Holocene paleoenvironmental evolution of the Black Sea, reconstructed with stable oxygen isotope records obtained on ostracod shells, Earth Planet. Sci. Lett., 241, 863-875, doi:10.1016/j.epsl. 2005.10.036.

Bahr, A., F. Lamy, H. W. Arz, C. Major, O. Kwiecen, and G. Wefer (2008), Abrupt changes of temperature and water chemistry in the late Pleistocene and early Holocene Black Sea, Geochem. Geophys. Geosyst., 9, Q01004, doi:10.1029/2007GC001683.

Ballard, R. D., D. F. Coleman, and G. D. Rosenberg (2000), Further evidence of abrupt Holocene drowning of the Black Sea shelf, Mar. Geol., 170, 253-261, doi:10.1016/S00253227(00)00108-0.

Besiktepe, S. (2003), Density currents in the twolayer flow: An example of Dardanelles outflow, Oceanol. Acta, 26, 243-253, doi:10.1016/ S0399-1784(03)00015-X

Boon, J. J., W. I. C. Rijpstra, F. De Lange, J. W. De Leeuw, M. Yoshioka, and Y. Shimizu (1979), Black Sea sterol-A molecular fossil for dinoflagellate blooms, Nature, 277, 125127, doi: $10.1038 / 277125 \mathrm{a} 0$

Bronshtein, Z. S. (1947), Freshwater Ostracoda: Fauna of the USSR Crustacea (in Russian), vol. 2, part 1, Amerind, New Delhi. (English translation, Russian Translation Series, vol. 64, Acad. of Sci. of the USSR, Moscow, 1988.)

Cacho, I., J. O. Grimalt, and M. Canals (2002), Response of the western Mediterranean Sea to rapid climatic variability during the last 50,000 years: A molecular biomarker approach, J. Mar. Syst., 33-34, 253-272, doi:10.1016/S09247963(02)00061-1.

Çağatay, M. N., N. Görür, O. Algan, C. Eastoe, A. Tchapalyga, D. Ongan, T. Kuhn, and I. Kuscu (2000), Late glacial-Holocene palaeoceanography of the Sea of Marmara: Timing of connections with the Mediterranean and the Black seas, Mar. Geol., 167, 191-206, doi:10.1016/S0025-3227(00)00031-1.

Capo, R. C., B. W. Stewart, and O. A. Chadwick (1998), Strontium isotopes as tracers of ecosystem processes: Theory and methods, Geoderma, 82, 197-225, doi:10.1016/S00167061(97)00102-X

Chepalyga, A. L. (1985), Inland sea basins, in Late Quaternary Environments of the Soviet Union, edited by A. A. Velichko, pp. 229247, Univ. of Minn. Press, Minneapolis.

Crusius, J., S. Calvert, T. Pedersen, and D. Sage (1996), Rhenium and molybdenum enrichments in sediments as indicators of oxic, suboxic and sulfidic conditions of deposition,
Earth Planet. Sci. Lett., 145, 65-78, doi:10.1016/S0012-821X(96)00204-X.

Danis, P.-A., U. von Grafenstein, and V. MassonDelmotte (2003), Sensitivity of deep lake temperature to past and future climatic changes: A modeling study for Lac d'Annecy, France, and Ammersee, Germany, J. Geophys. Res. 108(D19), 4609, doi:10.1029/2003JD003595.

Duplessy, J. C., E. Bard, M. Arnold, N. J. Shackleton, J. Duprat, and L. Labeyrie (1991), How fast did the ocean-atmosphere system run during the last deglaciation?, Earth Planet. Sci. Lett., 103, 27-40, doi:10.1016 0012-821X(91)90147-A

Elderfield, H. (1986), Strontium isotope stratigraphy, Palaeogeogr. Palaeoclimatol. Palaeoecol., 57, 71-90, doi:10.1016/0031-0182 (86)90007-6.

Emeis, K.-C., U. Struck, H.-M. Schulz, R. Rosenberg, S. Bernasconi, H. Erlenkeuser, T. Sakamoto, and F. Martinez-Ruiz (2000), Temperature and salinity variations of Mediterranean Sea surface waters over the last 16,000 years from records of planktonic stable oxygen isotope and alkenone unsaturation ratios, $\mathrm{Pa}$ laeogeogr. Palaeoclimatol. Palaeoecol., 158 259-280, doi:10.1016/S0031-0182(00) 00053-5.

Eriş, K. K., W. B. F. Ryan, M. N. Çağatay, U. Sancar, G. Lericolais, G. Ménot, and E. Bard (2007), The timing and evolution of the postglacial transgression across the Sea of Marmara shelf south of Istanbul, Mar. Geol., 243, 57-76, doi:10.1016/j.margeo.2007.04.010.

Essallami, L., M. A. Sicre, N. Kallel, L. Labeyrie, and G. Siani (2007), Hydrological changes in the Mediterranean Sea over the last 30,000 years, Geochem. Geophys. Geosyst., 8, Q07002, doi:10.1029/2007GC001587.

Ferreira, A. M., A. Miranda, M. Caetano, M. Baas, C. Vale, and J. S. Sinninghe Damste (2001), Formation of mid-chain alkane keto-ols by post-depositional oxidation of mid-chain diols in Mediterranean sapropels, Org. Geochem. 32, 271-276, doi:10.1016/S0146-6380(00) $00181-9$

Feurdean, A., S. Klotz, V. Mosbrugger, and B. Wohlfarth (2008), Pollen-based quantitative reconstructions of Holocene climate variability in NW Romania, Palaeogeogr. Palaeoclimatol. Palaeoecol., 260, 494-504, doi:10.1016/j. palaeo.2007.12.014

Gaudette, H. E., W. R. Flight, L. Toner, and D. W. Folger (1974), An inexpensive titration method for the determination of organic carbon in recent sediments, J. Sediment. Petrol. $44,249-253$.

Giunta, S., C. Morigi, A. Negri, F. Guichard, and G. Lericolais (2007), Holocene biostratigraphy and paleoenvironmental changes in the Black Sea based on calcareous nannoplankton, Mar Micropaleontol., 63, 91-110, doi:10.1016/ j.marmicro.2006.12.001.

Görür, N., et al. (2001), Is the abrupt drowning of the Black Sea shelf at 7150 yr BP a myth? Mar. Geol., 176, 65-73, doi:10.1016/S00253227(01)00148-7.

Griffiths, H. I., D. S. Martin, A. J. Shine, and J. G. Evans (1993), The ostracod fauna (Crustacea, Ostracoda) of the profundal benthos of Loch Ness, Hydrobiologia, 254(2), 111-117, doi:10.1007/BF00014315.

Harrison, S. P., G. Yu, and P. E. Tarasov (1996), Late Quaternary lake-level record from northern Eurasia, Quat. Res., 45, 138-159, doi:10.1006/qres.1996.0016.
Hemleben, C., M. Spindler, and M. Anderson (1989), Modern Planktonic Foraminifera, 363 pp., Springer, New York.

Hiscott, R. N., A. E. Aksu, P. J. Mudie, F. Marret, T. Abrajano, M. A. Kaminski, J. Evans, A. I. Çakiroğlu, and D. Yaşar (2007), A gradual drowning of the southwestern Black Sea shelf: Evidence for a progressive rather than abrupt Holocene reconnection with the eastern Mediterranean Sea through the Marmara Sea Gateway, Quat. Int., 167-168, 19-34, doi:10.1016/j.quaint.2006.11.007.

Hughen, K. A., et al. (2004), MARINE04 marine radiocarbon age calibration, 26-0 ka BP, Radiocarbon, 46, 1059-1086.

Jones, G. A., and A. R. Gagnon (1994), Radiocarbon chronology of Black Sea sediments, Deep Sea Res., Part I, 41, 531-557, doi:10.1016/0967-0637(94)90094-9.

Jones, M. D. C. N. Roberts, and M. J. Leng (2007), Quantifying climatic change through the last glacial-interglacial transition based on lake isotope palaeohydrology from central Turkey, Quat. Res., 67, 463-473, doi:10.1016/ j.yqres.2007.01.004.

Kaplin, P. A., and A. O. Selivanov (2004), Late glacial and Holocene sea level changes in semi-enclosed seas of North Eurasia: Examples from the contrasting Black and White seas, Palaeogeogr. Palaeoclimatol. Palaeoecol. 209, 19-36, doi:10.1016/j.palaeo.2004.02.016.

Kerey, I. E., E. Meriç, C. Tunoğlu, G. Kelling, R. L. Brenner, and A. U. Doğan (2004), Black Sea-Marmara Sea Quaternary connections: New data from the Bosphorus, Istanbul, Turkey, Palaeogeogr. Palaeoclimatol. Palaeoecol. 204, 277-295, doi:10.1016/S0031-0182(03) 00731-4

Kwiecien, O., H. W. Arz, F. Lamy, S. Wulf, A. Bahr, U. Röhl, and G. H. Haug (2008), Estimated reservoir ages of the Black Sea since the last glacial, Radiocarbon, 50, 99-118

Lambeck, K., Y. Yokoama, and T. Purcell (2002), Into and out of the Last Glacial Maximum: Sea-level change during oxygen isotope stages 3 and 2, Quat. Sci. Rev., 21, 343-360.

Lambeck, K., D. Sivan, and A. Purcell (2007) Timing of the last Mediterranean Sea: Black Sea connection from isostatic models and regional sea-level data, in The Black Sea Flood Question: Changes in Coastline, Climate and Human Settlement, edited by V. Yanko-Hombach, A. S. Gilbert, and N. Panin, pp. $797-$ 808, Springer, Heidelberg, Germany.

Lane-Serff, G. F., E. J. Rohling, H. L. Bryden, and H. Charnock (1997), Postglacial connection of the Black Sea to the Mediterranean and its relation to the timing of sapropel formation, Paleoceanography, 12(2), 169-174, doi:10.1029/96PA03934.

Leng, M. J., and J. D. Marshall (2004), Palaeoclimate interpretation of stable isotope data from lake sediment archives, Quat. Sci. Rev. 23, 811-831, doi:10.1016/j.quascirev.2003. 06.012

Major, C., W. Ryan, G. Lericolais, and I. Hajdas (2002), Constraints on Black Sea outflow to the Sea of Marmara during the last glacial-interglacial transition, Mar. Geol., 190, 19-34 doi:10.1016/S0025-3227(02)00340-7.

Major, C. O., S. L. Goldstein, W. B. F. Ryan, G. Lericolais, A. M. Piotrowski, and I. Hajdas (2006), The co-evolution of Black Sea level and composition through the last deglaciation and its paleoclimatic significance, Quat. Sci. Rev., 25, 2031-2047, doi:10.1016/j.quascirev. 2006.01.032 
Mangerud, J., et al. (2004), Ice-dammed lakes and rerouting of the drainage of northern Eurasia during the last glaciation, Quat. Sci. Rev, 23, 1313-1332, doi:10.1016/j.quascirev. 2003.12.009.

Marlowe, I. T., S. C. Brassell, G. Eglinton, and J. C. Green (1984), Long chain unsaturated ketones and esters in living algae and marine sediments, Org. Geochem., 6, 135-141, doi:10.1016/0146-6380(84)90034-2.

McHugh, C. M. G., D. Gurung, L. Giosan, W. B. F. Ryan, Y. Mart, U. Sancar, L. Burckle, and M. N. Çağatay (2008), The last reconnection of the Marmara Sea (Turkey) to the World Ocean: A paleoceanographic and paleoclimatic perspective, Mar. Geol., 255, 64-82.

Meisch, C. (2000), Süsswasserfauna von Mitteleuropa, vol. 8, part 3, Freshwater Ostracoda of Western and Central Europe, edited by J. Schwoerbel and P. Zwick, Spektrum Akad. Verl., Heidelberg, Germany.

Menzel, D., P. F. van Bergen, S. Schouten, and J. S. Sinninghe Damsté (2003), Reconstruction of changes in export productivity during Pliocene sapropel deposition: A biomarker approach, Palaeogeogr. Palaeoclimatol. Palaeoecol., 190, 273-287, doi:10.1016/ S0031-0182(02)00610-7.

Mercone, D., J. Thomson, R. H. Abu-Zied, I. W. Croudace, and E. J. Rohling (2001), High resolution geochemical and micropalaeontological profiling of the most recent eastern Mediterranean sapropel, Mar. Geol., 177, 25-44, doi:10.1016/S0025-3227(01)00122-0.

Mudie, P. J., A. Rochon, and A. E. Aksu (2002), Pollen stratigraphy of Late Quaternary cores from Marmara Sea: Land-sea correlation and paleoclimatic history, Mar. Geol., 190, 233 260, doi:10.1016/S0025-3227(02)00349-3.

Müller, P. J., G. Kirst, G. Ruhland, I. von Storch, and A. Rosell-Melé (1998), Calibration of the alkenone paleotemperature index $U_{37}^{K^{\prime}}$ based on core-tops from the eastern South Atlantic and the global ocean $\left(60^{\circ} \mathrm{N}-60^{\circ} \mathrm{S}\right)$, Geochim. Cosmochim. Acta, 62, 1757-1772, doi:10.1016/ S0016-7037(98)00097-0.

Myers, P. G., C. Wielki, S. B. Goldstein, and E. J. Rohling (2003), Hydraulic calculations of postglacial connections between the Mediterranean and the Black Sea, Mar. Geol., 201, $253-$ 267, doi:10.1016/S0025-3227(03)00225-1.

Nazik, A. (2001), Ostracode fauna of bottom sediments from the continental shelf, south Marmara Sea, NW Turkey, and their comparison with other shelf environments in the Mediterranean and Aegean regions, Geol. J., 36, 111-123, doi:10.1002/gj.886.

Oguz, T., and A. Merico (2006), Factors controlling the summer Emiliania huxleyi bloom in the Black Sea: A modeling study, J. Mar. Syst., 59, 173-188, doi:10.1016/j.jmarsys.2005.08. 002.

Özsoy, E., and Ü. Ünlüata (1997), Oceanography of the Black Sea: A review of some recent results, Earth Sci. Rev., 42, 231-272, doi:10.1016/S0012-8252(97)81859-4.

Palmer, M. R., and J. M. Edmond (1989), The Sr isotope budget of the modern ocean, Earth Planet. Sci. Lett., 92, 11-26, doi:10.1016/ 0012-821X(89)90017-4.

Pichler, H., and W. Friedrich (1976), Radiocarbon dates of Santorini volcanics, Nature, 262, 373-374, doi:10.1038/262373a0.

Piper, D. Z., and C. M. Isaacs (1995), Minor elements in Quaternary sediment from the Sea of Japan: A record of surface-water productivity and intermediate-water redox conditions, Geol. Soc. Am. Bull., 107(1), 54-67.
Popescu, I., G. Lericolais, N. Panin, A. Normand, C. Dinu, and E. Le Derzen (2004), The Danube submarine canyon (Black Sea): Morphology and sedimentary processes, Mar Geol., 206, 249-265, doi:10.1016/j.margeo. 2004.03.003

Prahl, F. G., L. A. Muehlhausen, and D. A. Zahnle (1988), Further evaluation of longchain alkenones as indicators of paleoceanographic conditions, Geochim. Cosmochim. Acta, 52, 2303-2310, doi:10.1016/0016-7037 (88) $90132-9$.

Ross, D. A., and E. T. Degens (1974), Recent sediments of Black Sea, in The Black SeaGeology, Chemistry, and Biology, edited by E. T. Degens and D. A. Ross, Mem. Am. Assoc. Pet. Geol., 20, 183-199.

Rostek, F., G. Ruhland, F. Bassinot, P. Müller, L. Labeyrie, Y. Lancelot, and E. Bard (1993) Reconstructing sea surface temperature and salinity using $\delta^{18} \mathrm{O}$ and alkenone records, Nature, 364, 319-321, doi:10.1038/364319a0.

Ryan, W. B. F., and W. C. Pitman III (1999), Noah's Flood: The New Scientific Discoveries About the Event That Changed History, 319 pp., Simon and Schuster, New York.

Ryan, W. B. F., W. C. Pitman III, C. O. Major, K Shimkus, V. Moskalenko, G. A. Jones, P. Dimitrov, N. Gorür, M. Sakinc, and H. Yüce (1997), An abrupt drowning of the Black Sea shelf, Mar. Geol., 138, 119-126, doi:10.1016/ S0025-3227(97)00007-8.

Ryan, W. B. F., C. O. Major, G. Lericolais, and S. L. Goldstein (2003), Catastrophic flooding of the Black Sea, Annu. Rev. Earth Planet Sci., 31, 525-554, doi:10.1146/annurev. earth.31.100901.141249.

Schiebel, R., and C. Hemleben (2000), Interannual variability of planktonic foraminiferal populations and test flux in the eastern North Atlantic Ocean (JGOFS), Deep Sea Res. Part II, 47, 1809-1852, doi:10.1016/S09670645(00)00008-4

Schornikov, E. I. (1969), Ostracoda, in Opredeliteli Fauna Cernogo i Azovskogomorei (Determination of the Fauna of the Black and Azov Sea), vol. 2, edited by F. D. Mordukai-Boltovskoi, pp. 163-259, Akad. Nauk USSR, Kiev.

Schulz, H.-M., A. Schöner, and K. U. Emeis (2000), Long-chain alkenone patterns in the Baltic Sea: An ocean-freshwater transition, Geochim. Cosmochim. Acta, 64, 469-477, doi:10.1016/S0016-7037(99)00332-4.

Siani, G., M. Paterne, M. Arnold, E. Bard, B. Métivier, N. Tisnerat, and F. Bassinot (2000), Radiocarbon reservoir ages in the Mediterranean Sea and Black Sea, Radiocarbon, 42, 271-280.

Simstich, J., M. Sarnthein, and H. Erlenkeuser (2003), Paired $\delta^{18} \mathrm{O}$ signals of Neogloboquadrina pachyderma (s) and Turborotalita quinqueloba show thermal stratification structure in Nordic Seas, Mar. Micropaleontol., 48, $107-$ 125, doi:10.1016/S0377-8398(02)00165-2.

Sonzogni, C., E. Bard, F. Rostek, D. Dollfus, A. Rosell-Melé, and G. Eglinton (1997), Temperature and salinity effects on alkenone ratios measured in surface sediment from the Indian Ocean, Quat. Res., 47, 344-355, doi:10.1006/ qres.1997.1885.

Sperling, M., S. Weldeab, and G. Schmiedl (2002), Drying of samples may alter foraminiferal isotopic ratios and faunistic composition, Micropaleontology, 48(1), 87-91.

Sperling, M., G. Schmiedl, C. Hemleben, K. C. Emeis, H. Erlenkeuser, and P. M. Grootes (2003), Black Sea impact on the formation of eastern Mediterranean sapropel S1? Evidence from the Marmara Sea, Palaeogeogr. Palaeoclimatol. Palaeoecol., 190, 9-21, doi:10.1016/ S0031-0182(02)00596-5.

Stuiver, M., and P. J. Reimer (1993), Extended ${ }^{14} \mathrm{C}$ data base and revised CALIB $3.0{ }^{14} \mathrm{C}$ age calibration program, Radiocarbon, 35, 215230.

Thiel, V., A. Jenisch, G. Landmann, A. Reimer, and W. Michaelis (1997), Unusual distributions of long-chain alkenones and tetrahymanol from the highly alkaline Lake Van, Turkey, Geochim. Cosmochim. Acta, 61, 2053-2064, doi:10.1016/S0016-7037(97)00038-0.

Tolun, L., M. N. Cağatay, and W. J. Carrigan (2002), Organic geochemistry and origin of late Glacial-Holocene sapropelic layers and associated sediments in Marmara Sea, $\mathrm{Mar}$ : Geol., 190, 47-60, doi:10.1016/S00253227(02)00342-0.

Tzedakis, P. C., M. R. Frogley, I. T. Lawson, R. C. Preece, I. Cacho, and L. de Abreu (2004), Ecological thresholds and patterns of millennial-scale climate variability: The response of vegetation in Greece during the last glacial period, Geology, 32, 109-112, doi:10.1130/G20118.1.

Ünlüata, Ü., T. Oguz, M. A. Latif, and E. Özsoy (1990), On the physical oceanography of the Turkish Straits, in The Physical Oceanography of Sea Straits, NATO ASI Ser., Ser. C, vol. 318, edited by L. J. Pratt, pp. 25-60, Kluwer Acad., Dordrecht, Netherlands.

Volkman, J. K., S. M. Barrett, S. I. Blackburn, M. P. Mansour, E. L. Sikes, and F. Gelin (1998), Microalgal biomarkers: A review of recent research developments, Org. Geochem. 29, 1163-1179, doi:10.1016/S0146-6380 (98)00062-X

Volkman, J. K., S. M. Barrett, and S. I. Blackburn (1999), Eustigmatophyte microalgae are potential sources of $\mathrm{C}_{29}$ sterols, $\mathrm{C}_{22}-\mathrm{C}_{28} n$-alcohols and $\mathrm{C}_{28}-\mathrm{C}_{32} n$-alkyl diols in freshwater environments, Org. Geochem., 30, 307-318, doi:10.1016/S0146-6380(99)00009-1.

Volkmann, R., and M. Mensch (2001), Stable isotopic composition $\left(\delta^{18} \mathrm{O}, \delta^{13} \mathrm{C}\right)$ of living planktic foraminifers in the outer Laptev Sea and the Fram Strait, Mar. Micropaleontol., 42, 163-188, doi:10.1016/S0377-8398(01)00018-4. von Grafenstein, U. (2002), Oxygen-isotope studies of ostracods from deep lakes, in The Ostracoda: Applications in Quaternary Research Geophys. Monogr. Ser., vol. 131, edited by J. A. Holmes and A. R. Chivas, pp. 249-266, AGU, Washington, D. C.

von Grafenstein, U., H. Erlenkeuser, and P. Trimborn (1999), Oxygen and carbon isotopes in modern fresh-water ostracod valves: Assessing vital offsets and autecological effects of interest for palaeoclimate studies, Palaeogeogr. Palaeoclimatol. Palaeoecol., 148 133-152, doi:10.1016/S0031-0182(98) 00180-1.

Wulf, S., M. Kraml, T. Kuhn, M. Schwarz, M. Inthorn, J. Keller, I. Kuscu, and P. Halbach (2002), Marine tephra from the Cape Riva eruption $(22 \mathrm{ka})$ of Santorini in the Sea of Marmara, Mar. Geol., 183, 131-141, doi:10.1016/S0025-3227(01)00302-4.

Xia, J., E. Ito, and D. R. Engstrom (1997), Geochemistry of ostracode calcite: Part 1 . An experimental determination of oxygen isotope fractionation, Geochim. Cosmochim. Acta 61, 377-382, doi:10.1016/S0016-7037 (96)00351-1

Yaltirak, C., M. Sakinc, A. E. Aksu, R. N. Hiscott, B. Galleb, and U. B. Ulgen (2002), Late 
Pleistocene uplift history along the southwestern Marmara Sea determined from raised coastal deposits and global sea-level variations, Mar. Geol., 190, 283-306, doi:10.1016/S00253227(02)00351-1.

Zheng, Y., R. F. Anderson, A. van Geen, and J. Kuwabara (2000), Authigenic molybdenum formation in marine sediments: A link to pore water sulfide in the Santa Barbara Basin, Geochim. Cosmochim. Acta, 64, 4165-4178, doi:10.1016/S0016-7037(00)00495-6
Zubakov, V. A. (1988), Climatostratigraphic scheme of the Black Sea Pleistocene and its correlation with the oxygen-isotope scale and glacial events, Quat. Res., 29, 1-24, doi:10.1016/0033-5894(88)90067-1.

E. Bard, H. Bruneton, C. Joly, G. Ménot, F. Rostek, and L. Vidal, CEREGE, Aix-Marseille
Université, Collège de France, IRD, Europôle de l'Arbois, CNRS, F-13545 Aix-en-Provence, France. (vidal@cerege.fr)

M. N. Cağatay, EMCOL, Istanbul Technical University, 34469 Istanbul, Turkey.

C. Major, Department of Geology and Geophysics, Woods Hole Oceanographic Institution, Woods Hole, MA 02543, USA. 